\title{
Health Research for Development Initiative in Vietnam (HRDI): Impact evaluation results
}

Katherine Williams

Population Council

Meiwita P. Budiharsana

Population Council

Nguyen Thi Phuong Lan

Population Council

Follow this and additional works at: https://knowledgecommons.popcouncil.org/departments_sbsr-rh

Part of the Health Services Research Commons, International Public Health Commons, Public Health Education and Promotion Commons, and the Social and Behavioral Sciences Commons How does access to this work benefit you? Let us know!

\section{Recommended Citation}

Williams, Katherine, Meiwita P. Budiharsana, and Nguyen Thi Phuong Lan. 2010. "Health Research for Development Initiative in Vietnam (HRDI): Impact evaluation results." Hanoi: Population Council. 
HEALTH RESEARCH FOR

DEVELOPMENT INITIATIVE IN VIETNAM (HRDI)

IMPACT EVALUATION RESULTS
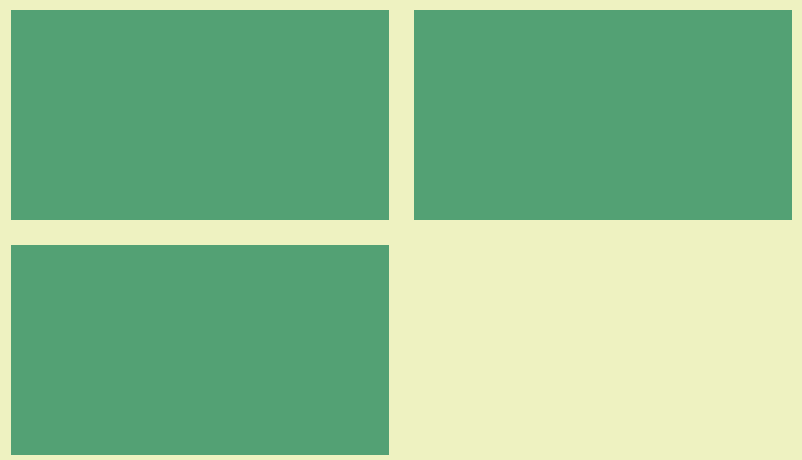

Katherine Williams

Meiwita Budiharsana

Nguyen Thi Phuong Lan

Population Council, Viet Nam Hanoi - December, 2009

(f Population Council 
(C) 2010 The Population Council, Inc.

\section{(2) Population Council}

The Population Council is an international, nonprofit, nongovernmental organization that conducts research worldwide to improve policies, programs, and products in three areas: HIV and AIDS; poverty, gender, and youth; and reproductive health.

Population Council - Viet Nam

No. 41 Le Hong Phong Street

Ba Dinh District

Hanoi, Viet Nam

pchanoi@popcouncil.org

www.popcouncil.org

Any part of this publication may be photocopied without permission from the authors or publisher, provided that publication credit is given and that copies are distributed free. Any commercial reproduction requires prior written permission from the Population Council.

Design and presentation:

Khanh Dung Printing, Advertising, Designing \& Trading Company

ISBN: 978-604-50-0010-6 
HEALTH RESEARCH FOR

DEVELOPMENT INITIATIVE IN VIETNAM (HRDI)

IMPACT EVALUATION

RESULTS

Population Council, Viet Nam Hanoi - December, 2009

12 Population Council 


\section{Katherine Williams}

\section{Meiwita Budiharsana}

Nguyen Thi Phuong Lan

\section{Population Council, Viet Nam}

Hanoi - December, 2009 


\section{ACKNOWLEDGEMENTS}

This evaluation report provides information about building health research capacity in Viet Nam between 2004 and 2009. The Population Council Viet Nam (PCVN) was privileged to join hands with the Hanoi School of Public Health and Ho Chi Minh City University of Medicine and Pharmacy - Faculty of Public Health to increase research skills, provide competitive awards and develop a network to link fellows to various national and international institutes and conferences.

We would like to thank all those who made this Health Research for Development Initiative (HRDI) program and research possible. The idea to invest in fellows who have returned to Viet Nam after undertaking training overseas in public health and social sciences would not have been possible without support from the Susan Thompson Buffett and the Ford Foundations.

Special thanks to colleagues at the Population Council who have provided guidance and technical support, including Dr. John Townsend in the Washington, DC office and Dr. Saroj Pachauri in the New Delhi Regional Office.

Our appreciation also goes to all the returned fellows who participated in the HRDI program and provided feedback in evaluation surveys, responded to additional requests for information, attended HRDI events and returned home to continue to improve the health and well-being of those living in Viet Nam. 


\section{TABLE OF CONTENTS}

1. Introduction and Background 5

2. Rationale and Objectives 11

3. Methodological framework 15

$\begin{array}{lr}\text { 4. Results } & 17\end{array}$

5. Conclusion 43

6. Appendix 49

\section{LIST OF TABLES}

Table 1: Demographics of returned fellows $\quad 22$

Table 2: Current position by gender 24

Table 3: Work sector over last 12 months by gender 26

$\begin{array}{ll}\text { Table 4: Strongest skills by gender } & 31\end{array}$

Table 5: Strongest skills by work sector 33

Table 6: Returned fellows' research methods skills 35

\section{LIST OF FIGURES}

Figure 1: Fellowship by gender $\quad 21$

Figure 2: Current position title 23

Figure 3: Work sector over last 12 months by gender 25

Figure 4: Chosen type of work for endline respondents $(n=44)$

Figure 5: Strongest skills $\quad 29$

Figure 6: Strongest skills by gender 31

Figure 7: Returned fellows' research methods skills 34

Figure 8: Returned fellows' statistical methods and analysis skills 36 
Figure 9 : Qualitative research methods and skills

Figure 10: Distribution of returned fellows who have conducted research 38

Figure 11: Timeline for conducting research

Figure 12: Returned fellows' satisfaction with current job and job aspects 41

Appendix: 2009 Prospective Evaluation Survey Questionnaire - August 2009 


\section{Introduction and Background}




\subsection{Brief description of the Health Research for Development Initiative (HRDI) project}

The HRDI project involves the collaboration of three institutions for the purpose of mobilizing the growing supply of health professionals well-trained in research, first to sustain their professional skills and development and second, to apply their skills to advance health and development in Viet Nam as effectively as possible. The three institutions involved in this initiative are Hanoi School of Public Health (HSPH), Ho Chi Minh City University of Medicine and Pharmacy (UMP) - Faculty of Public Health (FPH), and Population Council in Viet Nam (PCVN).

The core target population of the project is Vietnamese health professionals who have studied overseas and have obtained recent master's degrees in public health or health social sciences under three fellowship programs managed by the Population Council and funded by the Susan Thompson Buffett Foundation and the Ford Foundation (Ford and Ford/SSRC fellowships). There are over 120 returned fellows (RFs) who have completed their degrees under these programs.

The rationale for HRDI is to insure a high return on the major investments made in overseas graduate training for Vietnamese health professionals. It is vital that this large group of well-trained health professionals apply their new skills to the fullest to advance public health and well being, especially among poor and vulnerable groups in Viet Nam.

While some returned fellows are holding faculty and other senior positions, others are working in provincial jobs or in busy clinical facilities. We see similar issues among recent graduates from programs of other sponsors. Consequently, we are eager to mobilize this talent pool in new ways that are efficient and effective, and to evaluate and share the results with other programs that also have returnees from overseas and other graduate degree programs.

HRDI has a number of strengths which are important advantages in achieving its goals. It represents a genuine, already-functioning partnership among HSPH, UMP, and PCVN. The proposal and project activities have been jointly developed, through extensive correspondence and meetings including a two-day planning workshop held in February 2004 with top representatives from each institution. All three partners are committed to 
sharing responsibility for the project, with each partner leading on some HRDI activities and assisting on others. Their commitment has been reinforced by the successful pilot implementation of several HRDI activities, including the Annual Scientific Meeting, which had strong participation by all partners, and the E-connect list serve. Finally and perhaps most importantly, many returnees have demonstrated their participation and enthusiasm for HRDI by their feedback on the proposed activities; and their active participation in the Annual Scientific Meetings held since 2003.

The partner institutions initially designed four categories of non-degree in-country capacity building activities in health research: first, opportunities for skills exchange and upgrades (including placements into research teams, short courses to increase skills, teaching placements as well as technical assistance in writing for publications); second, incentive awards to be granted to individuals and joint research projects as well as to management and development opportunities; third, the Annual Scientific Meetings hosted every year for returned fellows to present individual research findings and to discuss the development and improvement of the HRDI program; fourth, partner institutions coordinate an "E-connect" listserve that serves to connect all returned fellows, provide an electronic newsletter and encourage communication and networking among HRDI fellows.

When the program plan was carried through, some project activities were not implemented as there were limitations in resources and capacity, as well as a lack of interest on behalf of the returned fellows, particularly as time got further from the project's initiation. Below is a list of the activities that we actually carried through:

\section{Skills Exchanges and Upgrades}

- Placements to upgrade research skills, especially as students in existing short courses in advanced research skills;

- Technical assistance in writing for publication.

\section{Incentive awards}

- Individual or joint research projects pilot studies and proposal development of up to $\$ 3,000$; or 
- Management and professional development, e.g., to be trained in communications skills; or for travel costs to present a paper at a scientific conference.

\section{Annual National Scientific Meeting}

- For attendance by all fellows; returnees' research paper presentations chosen by competition.

\section{E-Connect}

- Email list-serve for all returned fellows, including web-search tips and links to online data and other resources;

- Electronic Newsletter;

- HRDI sections of existing Websites based at HSPH and UMP.

The Health Research for Development Initiative is a five-year project with two phases. The Phase I - Pilot/Feasibility Assessment Stage spanned 18 months and encompassed two objectives: to pilot each activity to test basic feasibility, and to refine each activity for its wider use. At the February 2004 HRDI Partners Workshop, all participants agreed that placements on research teams, placements in short courses in advanced research skills, small research grants, an Annual Scientific Meeting and E-Connect would be the main activities of the Phase I pilot of HRDI.

Phase II - Implementation and Evaluation - spanned the balance of the 5-year period and served as the basis for the Process and Impact Evaluations. During Phase II, those activities that proved to be most effective and sustainable during Phase I were expanded. In addition, the research knowledge and skills of returned fellows were evaluated by selfassessment at the initiation and completion of their participation in the HRDI program with questionnaires that served to inform an impact evaluation. The target population is those returnees who have demonstrated a strong interest in research in sexual and reproductive health and rights (SRH). The prospective evaluation commenced at the start of Phase II of the project in May 2006 and endline data collection was completed in August, 2009. 
This report summarizes findings from Phase II of the project, highlighting the results from the endline questionnaire as well as comparisons between the endline and the baseline questionnaire administered to returned fellows after pilot phase of HRDI. 


\section{Rationale and Objectives}




\subsection{Rationale of the project evaluation}

Although the HRDI project has a very strong rationale, it is a new model which has no specific precedent. Therefore the project implementers, its donors and other organizations planning similar capacity building activities are eager to learn from the project to see whether it is justifiable, whether it can be improved in the process of implementation and whether it is successful and should be a model for other projects of the same goals. In the initial project proposal, all three partners agreed HRDI should include the component of a prospective evaluation.

\subsection{Evaluation objectives}

The HRDI program as a whole has been evaluated using three different evaluation activities. Listed below are the three general evaluation activities and the intentions of each.

\section{Situation analysis}

- To document the areas where knowledge and skills of returned fellows need improvement,

- To identify barriers which limit the extent to which returned fellows are able to apply their knowledge and skills.

\section{Process evaluation}

- To gather feedback and impressions from returned fellows participating in program,

- To determine any factors that may be hindering the returned fellows' participation. 
- To document the knowledge and skills that returned fellows have obtained through the program,

- To explore the extent to which the project has contributed to the professional development and research skills of returned fellows.

Findings in this report are drawn from the Impact Evaluation activities only. Results from the Situation Analysis and the Process Evaluation are detailed in other intermediate reports on the HRDI program.

The main objective of the impact evaluation is to compare the self-assessment of research skills and knowledge as well as professional status and satisfaction among returned fellows before and after their participation in the HRDI program. Data collected about the following information contributes to a comprehensive understanding of the success, the impact and the potential for replication or improvement of the HRDI returned fellows program:

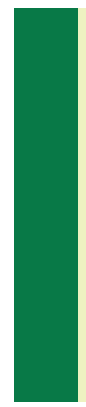

- Job position, job sector and change in field,

- Type of work and change in type of work,

- Technical skills and their utilization in a professional setting,

- Research and statistical skills and their utilization in a professional setting,

- Participation and intentions to conduct research,

- Satisfaction with current job position and professional situation. 


\section{Methodological framework}

The data collection's methodological framework includes two main components: evaluation surveys and ongoing data collection.

The evaluation survey included a baseline survey at the completion of HRDI's pilot project, in 2006, and an endline survey administered after three years of HRDI program, in 2009. The baseline survey measured the initial characteristics of RFs, their skills in undertaking research, the research they completed before being involved in the HRDI project, the level of use of scientific and research evidence to guide the practice and decision making of health staff in their organizations, and their training needs. The post intervention measures much of the same information as the baseline, for comparison and investigation of any changes.

Ongoing data collection on project activities and documentation of the RF's involvement and attendance in these activities is also part of the evaluation's methodological framework. Information from this data collection includes: an understanding of attitude and perceptions about training topics and objectives, the quality of course delivery and material, the effectiveness of the course and the skills acquired from the program and from research projects. This information was pertinent to the process evaluation, yet is not used as readily in the impact evaluation.

All the data collected by the evaluation is organized into a database. The database is used for maintaining the information of the separate surveys, RFs' profiles and HRDI activities. The maintenance of the database is a key element of the evaluation. 
16 HRDI - Impact Evaluation Results 


\section{Results}

This report is a summary analysis of the impact evaluation, including comparisons of the baseline information that was obtained through a survey of the same fellows undertaken at the end of 2006, and the endline information that was obtained through a survey of fellows in mid-2009, after completion of the HRDI program. This report also draws on findings from previous reports, including Philip Guest's Baseline Assessment (August 2007) and Phuoc Pham Van's Situation Analysis and Needs Evaluation. This Situation Analysis was done as part of a research placement under HRDI. 


\subsection{Data}

Baseline surveys were sent out and returned between May 2006 and November 2006. The baseline survey was completed by 92 of the 127 fellows for which the project database had contact information - a completion rate of 72 percent. Of the 35 RFs in the database who did not complete a questionnaire, it is known that six were studying for a $\mathrm{PhD}$ at universities outside of Viet Nam and could not be contacted. Of the remaining 29, 15 have returned but could not be contacted, one had died, and one dropped out. It is believed that 12 did not return to Viet Nam after completing their fellowships.

The endline survey was sent out to all 127 returned fellows between June 2009 and August 2009. 44 returned fellows returned the survey: 21 females and 23 males. This is a response rate of 34 percent. Explanations for this low response rate include the long time between baseline and endline surveys with the inevitable waning of interest or sense of obligation to the program, the high and demanding job obligations returned fellows have inhibiting them from completing and returning endline surveys, and anecdotal evidence suggests that many returned fellows thought the questionnaire was too long to answer. This lower rate is consistent with the range of response rates in follow-up surveys of graduates in many academic programs.

Analysis of the 44 returned fellows who returned the endline survey ("Responders") and the 83 returned fellows who did not return the endline survey ("Non Responders") was conducted to investigate any potential differences between the samples. Upon analysis of gender, fellowships and work status, there was no significant difference between the two populations. Both groups consisted of fewer than $50 \%$ males and over $50 \%$ females. There was no difference in the work status of the responders compared to the nonresponders. Each group consists of approximately 50\% government employees, 30\% non-government sector employees and over $10 \%$ of self-employed, self-employed and students.

Baseline and endline data were analyzed using Stata statistical software. Comparisons were made between original 92 baseline respondents and 44 endline respondents, as well as for the matching 44 respondents for particular variables. Stratifications by gender, work sector and other variables, as well as chi-square significance tests, were calculated for relevant variables. 
The baseline questionnaire included 92 respondents and the endline questionnaire included 44 respondents of the original 127 fellows. Some of the information presented below is available for all original 127 fellows. Unfortunately, incomplete questionnaires and/or incorrect formatting in the responses to some of the baseline and endline questionnaires that were returned have lead to inconsistencies in data for some questions. Because of these inconsistencies, sample size for some of the analyzed variables is smaller than the actual number of respondents.

Additionally, after analysis of, and feedback from, the baseline questionnaire, many of the questions in the endline survey were reworded and/or reformatted. This change in the data collection was made to gain a better understanding of the returned fellow's experience and skills as well as to more accurately collect the information of interest. These changes in wording and format have compromised the comparability of the baseline and endline versions of particular questions and variables. These inconsistencies are documented along with the applicable findings and are taken into consideration in the analysis of the results.

\subsection{Characteristics of Returned Fellows}

Figure 1 below presents the type of fellowship that all 127 returned fellows participated in by gender. There were two types of fellowships managed by Population Council, one hosted by the Susan Thompson Buffett Foundation, and two others hosted by the Ford Foundation. The Ford/SSRC was a Ford-supported fellowship entitled Social Science Research Council; seven students were involved in this program, indicated in the third set of bars in the Figure. The data represent the distribution of all 127 RFs, independent of their response to the baseline and endline surveys, demonstrating more males than females participating in the Buffett Fellowship (57 versus 41 respectively, to total 98 RFs) and more females than males participating (14 versus 8 respectively, to total 22 RFs) in the Ford Fellowship. A total of 7 returned fellows participated in the Ford/SSRC Fellowship, 3 of them were male and 4 were female. 
Figure 1: Fellowship by gender

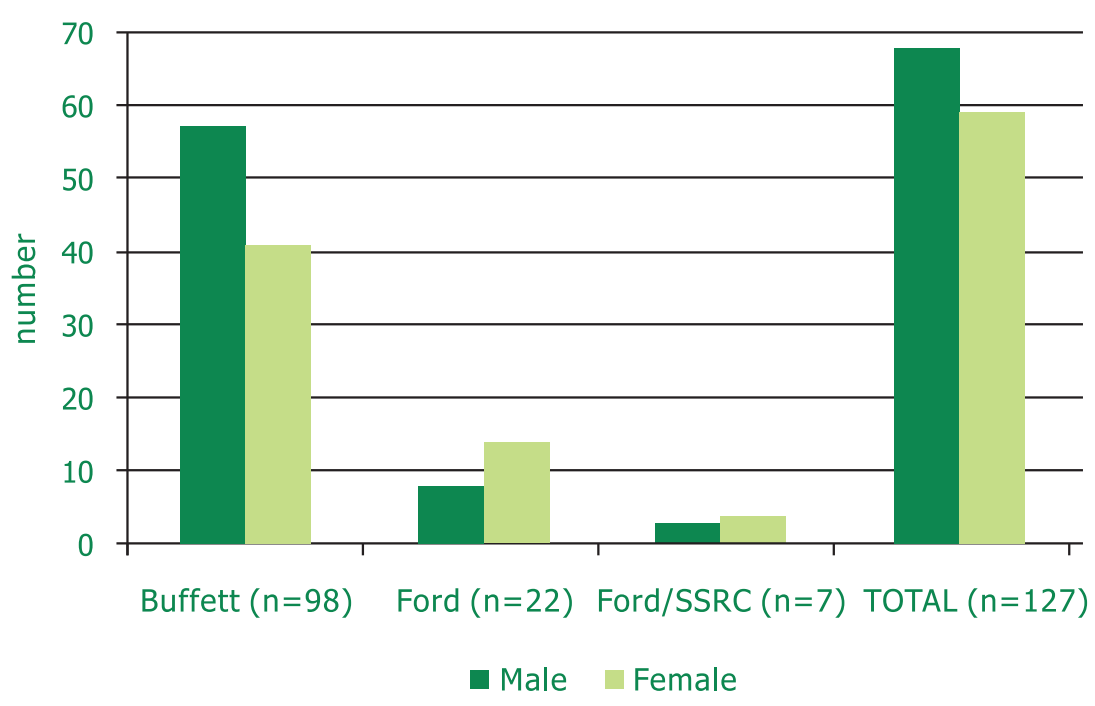

When analyzing responses to the endline survey, distribution of fellowships is as follows: 32 (72.7\%) from Susan Thompson Buffett Foundation, 9 (20.5 \%) from Ford Foundation and $3(6.8 \%)$ from Ford/SSRC Fellowship. The distribution of fellowships across responders to the endline survey is in line with the overall distribution of fellowships across the entire population of returned fellows.

Data on the demographic characteristics of all returned fellows was collected in the baseline survey; some of this information in presented in Table 1 below. From data including the 92 returned fellows who responded to the baseline, the gender distribution is as follows, $45 \%$ female and $55 \%$ male. Also, the ages of the returned fellows range from 30 to above 45 , with the majority between the ages of 35 and 39 , when the program began in 2006. 
Table 1: Demographics of returned fellows

\begin{tabular}{|l|c|c|}
\hline Characteristic & N & Percent \\
\hline Sex & & \\
\hline Female & 41 & 44.6 \\
\hline Male & 51 & 55.4 \\
\hline Total & 92 & 100.0 \\
\hline Age & & \\
\hline $30-34$ & 24 & 26.1 \\
\hline $35-39$ & 42 & 45.7 \\
\hline $40-44$ & 16 & 17.4 \\
\hline 45 and above & 10 & 10.9 \\
\hline Total & 92 & 100.0 \\
\hline
\end{tabular}

The current place of residence of returned fellows in both the baseline and the endline surveys is of particular interest as the HRDI program enrolled fellows who pursued degrees outside of Viet Nam. In the baseline questionnaire of 2006, of the 127 fellows, two-thirds (68 percent) had returned to Viet Nam after completing their Masters and were currently living there. A further 22 percent were studying for their PhD (one-fifth of which are in pursuing a PhD in Viet Nam, the rest outside of the country). When the endline questionnaire was collected, 2 of the 44 returned fellows (5\%) reported residing outside of Viet Nam, one pursuing a PhD in the United States and the other participating in a post-doctorate fellowship in Australia (data not shown). 


\subsection{Professional positions and sectors}

Figure 2: Current position title

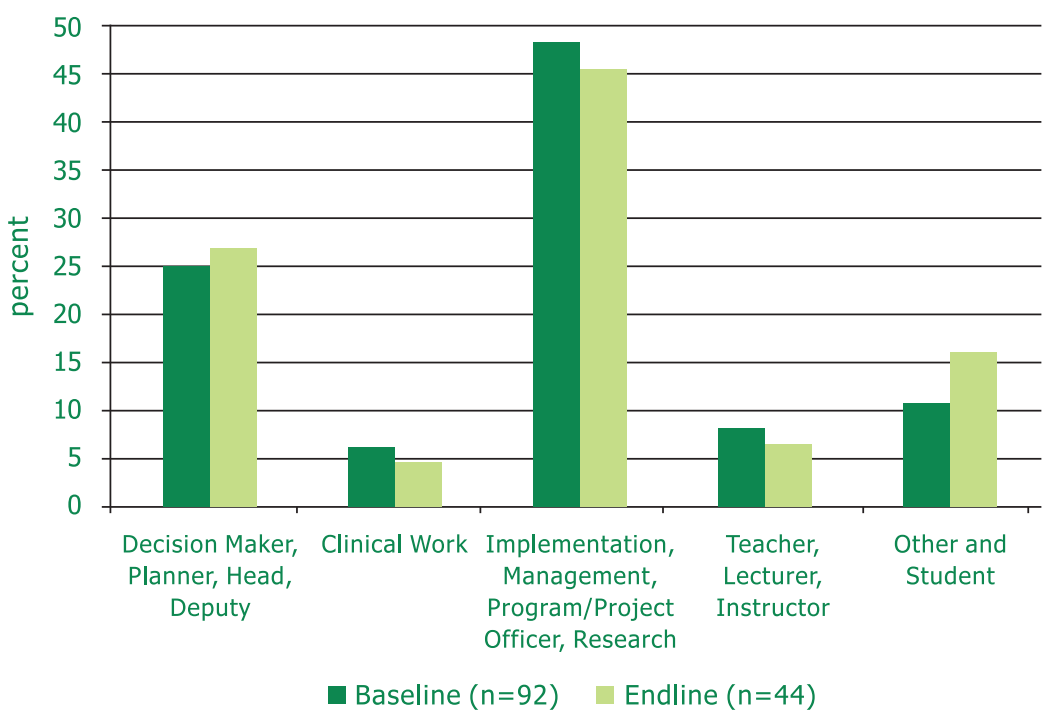

Analysis of the current position title for the returned fellows who responded to the baseline and the returned fellows who responded to the endline questionnaires is presented in Figure 2. In the baseline questionnaire, 48.9 percent worked in implementation, management, program officer or in research, and 25.5 percent of respondents indicated that they worked as a decision maker, planner, head or deputy. Other positions included teacher, lecturer and instructor ( 8.5 percent), clinical work (6.4 percent) and student/ other (10.6 percent). In the endline questionnaire, a slightly higher percentage of respondents indicated working as a "decision maker, planner, head and deputy" than in the baseline ( 27.3 percent) and fewer respondents indicated working in a clinical position (4.6 percent), in implementation, management, as a program officer or in research (45.5 percent), or as a teacher, lecturer or instructor (6.8). More RFs identified themselves as a student or other in the endline (15.9 percent) compared to the baseline (10.6 percent). The breakdown of this final group is made up of students (baseline $n=8$, endline $n=5$ ) as well as those who self-identify as consultants (baseline $n=2$, endline $n=2$ ). 
Independent of analysis in the changes in current position between the baseline and endline questionnaires, it is clear that implementation, management, program officiating and research positions are the most frequent occupational positions for research fellows both before and after participation in the HRDI program, representing between 45 and 50 percent of returned fellows. Also, as more RFs are in positions of decision making, management, and students, less are serving in clinical positions and teaching positions which represent less than 10 percent of returned fellows in both baseline and endline results.

When interpreting current position by gender, it is clear that there is difference in gender composition within certain positions, yet not all (Table 2). At the baseline, a similar proportion of men and women worked in the position of implementation, management, program officer or research (28 and 21 percent respectively). Although the percentage of RFs working in this field declined in the endline survey, more females indicated working in this field as compared to men (32 compared to 13 percent respectively). The gender composition in other positions remained relatively proportionate to the overall gender composition of RFs, indicating slightly more males than females. More males reported working as decision makers, planners, heads and deputies in both baseline and endline questionnaires. Men also reported working more regularly in clinical work, where interestingly, no women indicated a clinical position in the endline survey.

Table 2: Current position by gender

\begin{tabular}{|c|c|c|c|c|c|c|}
\hline \multirow{3}{*}{ Decision maker, planner, head, deputy } & \multicolumn{3}{|c|}{ Baseline $\%(n=92)$} & \multicolumn{3}{|c|}{ Endline $\%(n=44)$} \\
\hline & \multirow{2}{*}{25.5} & male & 13.8 & \multirow{2}{*}{27.3} & male & 18.2 \\
\hline & & female & 11.7 & & female & 9.1 \\
\hline \multirow{2}{*}{ Clinical Work } & \multirow{2}{*}{6.4} & male & 5.3 & \multirow{2}{*}{4.6} & male & 4.6 \\
\hline & & female & 1.1 & & female & 0 \\
\hline \multirow{2}{*}{$\begin{array}{l}\text { Implementation, management, Program Officer, } \\
\text { research }\end{array}$} & \multirow{2}{*}{48.9} & male & 27.7 & \multirow{2}{*}{45.5} & male & 13.6 \\
\hline & & female & 21.3 & & female & 31.8 \\
\hline \multirow{2}{*}{ Teaching, lecturing, instructor } & \multirow{2}{*}{8.5} & male & 5.3 & \multirow{2}{*}{6.8} & male & 4.6 \\
\hline & & female & 3.2 & & female & 2.3 \\
\hline \multirow{2}{*}{ Other, student } & \multirow{2}{*}{10.6} & male & 4.6 & \multirow{2}{*}{15.9} & male & 11.4 \\
\hline & & female & 6.4 & & female & 4.6 \\
\hline
\end{tabular}


Returned fellows also worked within different work sectors: government, non-government and those categorizing themselves as a student or self-employed. Results from the two surveys demonstrate that the percentage of RFs working in the government sector declined over the three-year period between baseline and endline questionnaires from 52 to 36 percent respectively. At the same time, the percentage of RFs in the nongovernment sector increased from 35 to 43 percent. This change could be a result of the higher level of income present within the non-government sector, attracting returned fellows from the high demand and low earning positions that are prevalent within the government sector. The percentage of returned fellows identifying as self-employed or as students increased in the endline study, after the HRDI program, as well. About 13 percent of returned fellows indicated they were students or self-employed in the baseline and 20 percent in endline.

Figure 3: Work sector over last 12 months by gender

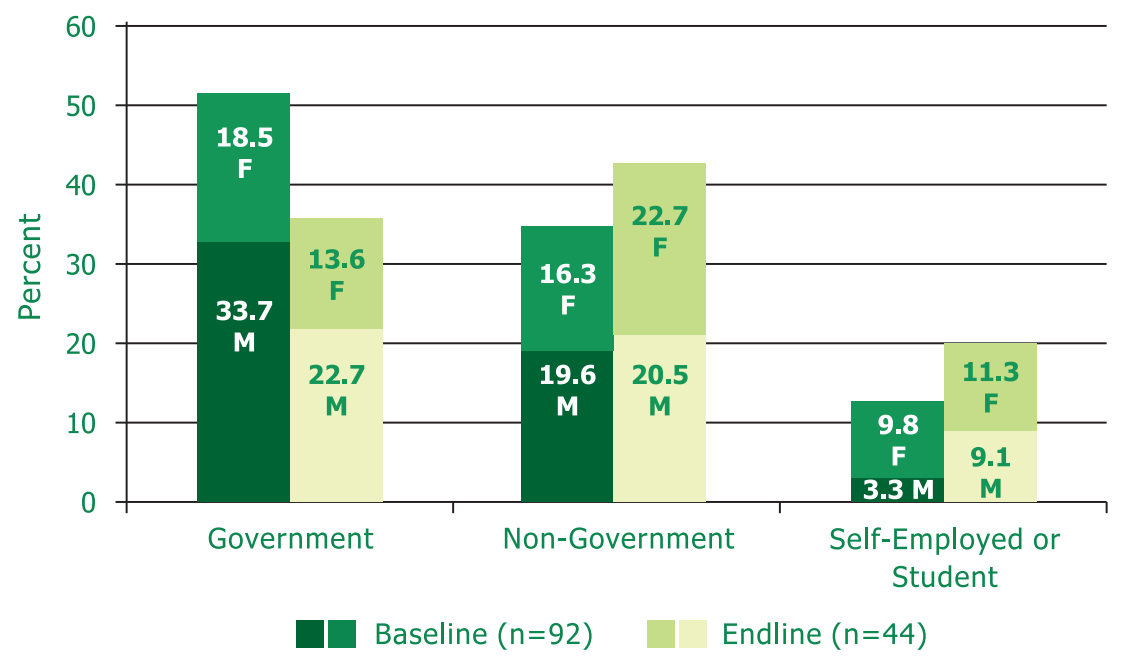

Distribution of work sector by gender in baseline and endline is presented in Figure 3 and Table 3 below. The percentage of males and females in the government and the nongovernment sector remained relatively consistent between the baseline and the endline surveys. Yet, in the self-employed and student category, the increase in percentage of RFs in this work section is mainly attributed to an increase in the number of men entering 
PhD programs or becoming self-employed, rather than women. At baseline, 25 percent (3.3/13) of fellows reported being self-employed or students were males; in the endline questionnaire, 55 percent (11.3/20.5) of this group was represented by males.

Table 3: Work sector over last 12 months by gender

\begin{tabular}{|c|c|c|c|c|c|c|}
\hline & & eline \% ( & $=92)$ & & dline \% & $=44)$ \\
\hline \multirow{2}{*}{ Government } & \multirow{2}{*}{52.2} & male & 33.7 & \multirow{2}{*}{36.4} & male & 22.7 \\
\hline & & female & 18.5 & & female & 13.6 \\
\hline \multirow{2}{*}{ Non Government } & \multirow{2}{*}{35.8} & male & 19.6 & \multirow{2}{*}{43.2} & male & 20.5 \\
\hline & & female & 16.3 & & female & 22.7 \\
\hline \multirow{2}{*}{$\begin{array}{l}\text { Self-employed or } \\
\text { Student }\end{array}$} & \multirow{2}{*}{13.0} & male & 3.3 & \multirow{2}{*}{20.5} & male & 9.1 \\
\hline & & female & 9.8 & & female & 11.3 \\
\hline
\end{tabular}

In addition to the particular work sector of RFs, analyzing the chosen type of work provides insight into the actual professional activities and projects that returned fellows were participating in on a daily basis during and after the HRDI program. In Figure 3 below, RF's chosen type of work collected from the endline survey is presented. At the endline, 14 of the 44 respondents (31.8 percent) indicated that they worked within the Training and Teaching sector. 9 returned fellows (20.5 percent) indicated Research in the endline, 8 (18.2\%) indicated Policy/Advocacy and 6 (13.6\%) indicated Service Delivery. These results indicate the majority of endline returned fellows in training and teaching, despite results in Table 1 which indicate that only 6.8 percent of returned fellows identify their current position as "teacher, lecturer or instructor". Interpretation of these results may indicate that returned fellows are training others within their current positions, yet not particularly teaching students and/or delivering lectures in an academic setting. 
Figure 4: Chosen type of work for endline respondents $(n=44)$

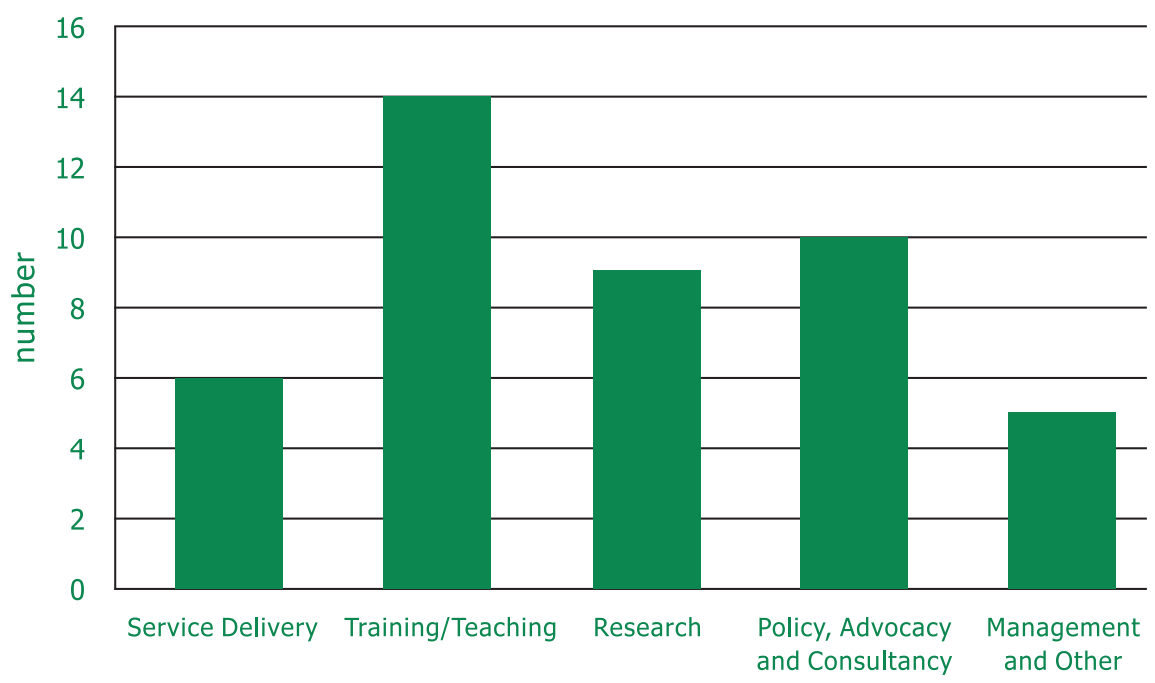

When comparing the endline results with those of the baseline, it is important to be aware of the different format of the questions. In the endline survey, respondents were asked to indicate one type of work in which they would consider their primary type of work; results are presented in Figure 4. In the baseline survey, respondents were able to indicate more than one area of work, making the results of the two questionnaires not directly comparable. Because any observed changes in these rates are not necessarily indicative of an actual change in chosen type of work, a more in-depth analysis was conducted.

To better understand any potential transition in chosen type of work from the beginning to the completion of returned fellows' participation in the HRDI program, the chosen type of work in endline was stratified by the chosen type of work indicated in the baseline questionnaire. Those respondents who indicated that they worked in service delivery in the baseline survey $(n=7)$, chosen type of work indicated in the endline was as follows: the majority remained in the service delivery sector in the endline survey $(n=3), 2$ RFs transitioned into policy, advocacy and consultancy work, one worked in training/teaching and one indicated working in management or other. Interestingly, none of the respondents 
entering the HRDI program from the service delivery field reported transitioning into the field of research in the endline survey. Additionally, the data demonstrate that the only fellows reporting to work in the service delivery sector at endline were those who indicated working in service delivery in baseline; no research fellows transferred into the service delivery field from another sector between baseline and endline.

Among those who indicated that they worked in the field of training and teaching at baseline in $2006(n=19)$, the majority remained in this field ( 9 of 19, 47.3 percent) and a proportion transferred to other fields including research ( 4 of 19, 21.1 percent), policy, advocacy and consultancy, and management (both indicated by 3 of 19 respondents, 15.8 percent each).

Twenty-two of the baseline respondents (51.2 percent) indicated that they chose to work in research. Seven (31.8 percent) of these respondents reported working in research at endline. The other professional fields that returned fellows transitioned into from research included: training and teaching ( 9 of 22, 40.9 percent), policy, advocacy and consultancy ( 3 of 22, 13.6 percent) and management (13.6 percent).

Baseline data, as well as the transition data from baseline to endline, indicate that the most popular type of work for returned fellows is the field of training and teaching (14 of 44, 32 percent). Additionally, many RFs are transferring from one type of work into another, out of the field of service delivery and into fields of training/teaching, research, policy, advocacy and consultancy, and management. Because of the difference in the questions' structures in the baseline and endline questions, it is difficult to assess any sample-level transition in type of work.

The number of research fellows indicating research as their primary type of work is small. At the same time, research methods and skills are incorporated into all types of work, including training/teaching, and management. Additionally, survey results presented later in the report indicate that fellows are utilizing research skills and activities within all professional positions, despite the majority of them indicating that they do not work primarily in research. 


\subsection{Professional activities and skills}

Assistance to attend training courses to learn new skills and update existing skills is a cornerstone of the HRDI project. To evaluate the impact of some of these training courses as well as the impact of returned fellows' participation in the HRDI, self-assessed strongest skills were assessed in baseline and endline surveys.

In the two surveys, returned fellows were asked to identify their strongest skills in regards to professional ability. In the baseline survey, returned fellows were instructed to choose the top three strongest skills; in endline, RFs were asked to rank them. The skills ranked in category 1, 2, and 3 in the endline were considered comparable to the three indicated strongest skills in the baseline. As each respondent chose more than one response for their strongest skill, the percentages do not add up to 100.

Figure 5: Strongest skills

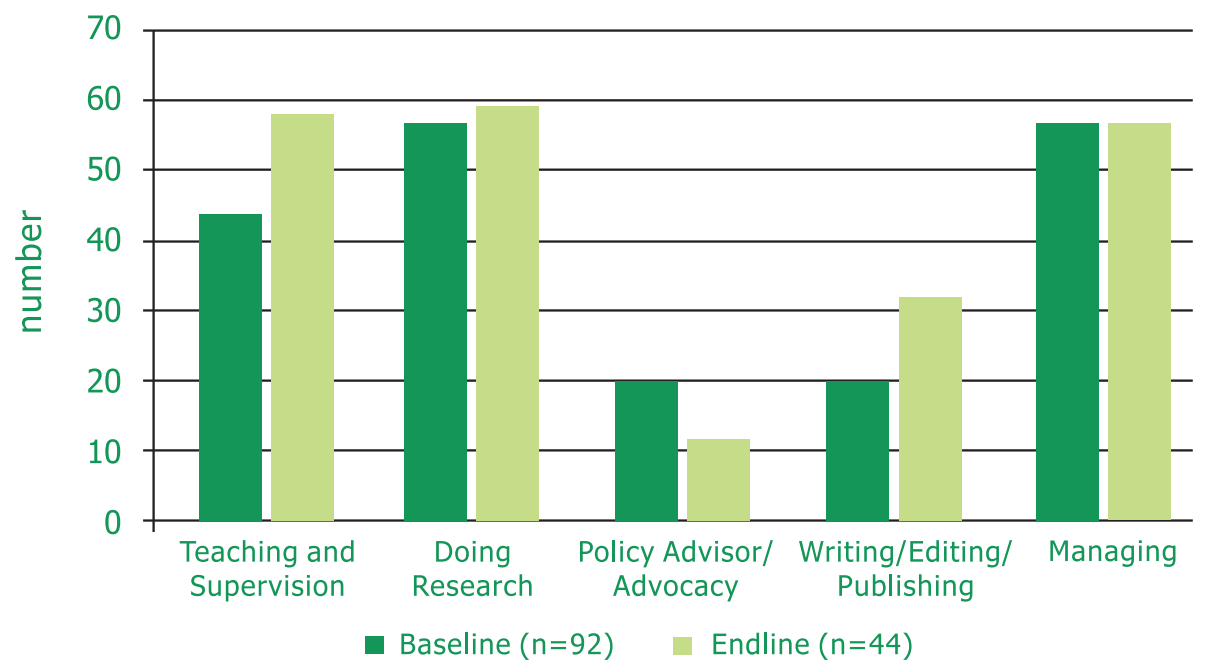

From the results, displayed in Figure 5, "teaching and supervising", "doing research", and "managing" were identified as the three strongest skills in baseline and endline surveys. Differences in the rates of these identified skills existed in the two individual surveys, 
some increasing and others decreasing. Of particular interest is the increase in almost all of the acknowledged strongest skills: "teaching/ supervising", "doing research", and a slight increase in "managing". The most significant increase was in the field of "training and supervision", increasing from 43.5 to 58.0 percent. There was also a noteworthy increase in "writing, editing and publishing" from 19.6 to 31.8 percent between baseline and endline. The only decrease in acknowledged strongest skills was in the field of "policy and advocacy" from 19.6 to 11.3 percent, which may be indicative of a lack of focus on this skill in the HRDI program activities and training courses.

Despite the low rates of research fellows indicating their primary positions and/or field of work in research, it is clear from these results that skill in conducting research as well as other research-oriented activities, such as writing/ editing/ publishing, is high and are improved even further after participation in the HRDI program.

When the strongest skills variable is stratified by gender, as seen in Figure 6 and Table 4 below, the majority of skills are distributed similarly to the overall gender structure of the respondents: slightly over 50 percent male, and slightly less than 50 percent female. Certain skills in the baseline had a gender distribution different than the overall sample percentage, with "policy advisor and advocacy", "writing, editing and publishing" and "managing" represented by a larger proportion of male respondents than the overall sample population. In the endline, gender representation flipped in some of the acknowledged strongest skills, with slightly more females than males indicating "doing research" and "policy advisor and advocacy" as one of their strongest skills. Refer to Table 4 for the differences in percentage distribution of skills by gender. 
Figure 6: Strongest skills by gender

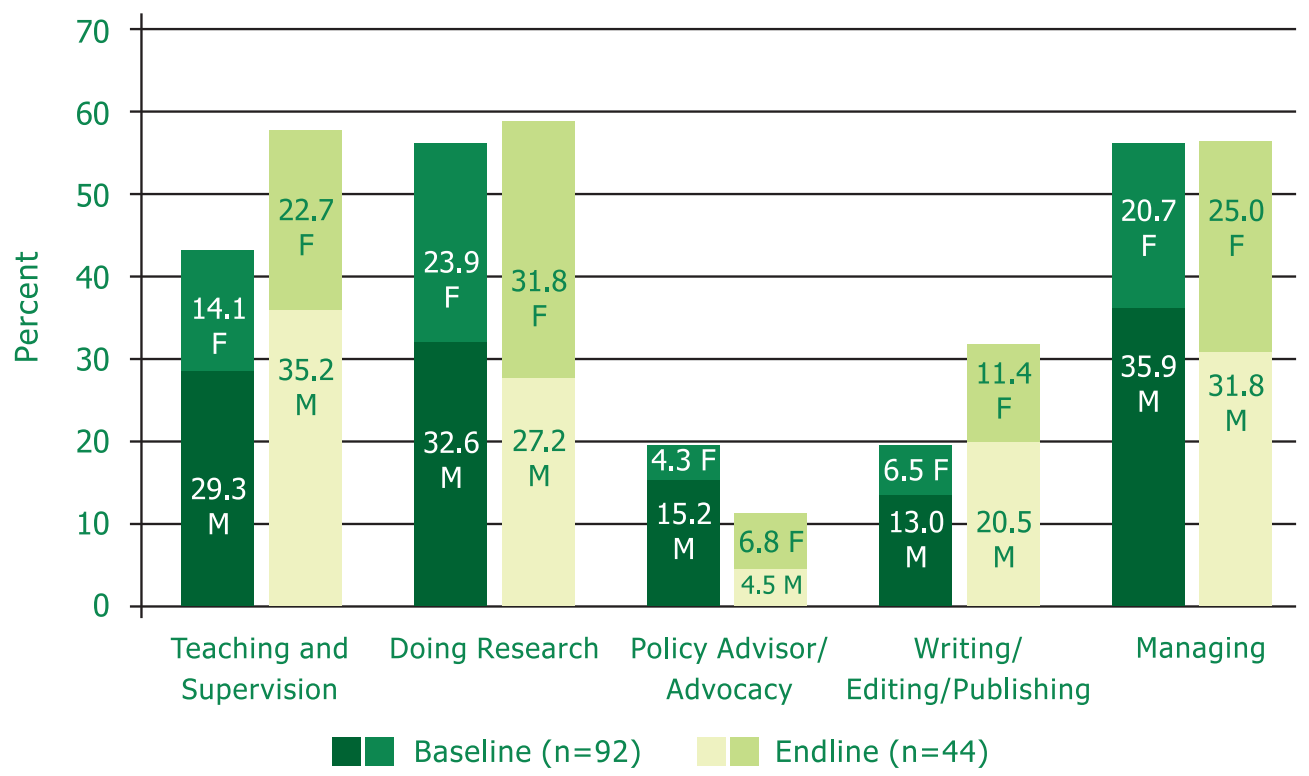

Table 4: Strongest skills by gender

\begin{tabular}{|c|c|c|c|c|c|c|}
\hline \multirow{3}{*}{ Teaching/supervising } & \multicolumn{3}{|c|}{ Baseline \% $(n=92)$} & \multicolumn{3}{|c|}{ Endline \% $(n=44)$} \\
\hline & \multirow{2}{*}{43.5} & male & 29.3 & \multirow{2}{*}{58} & male & 35.2 \\
\hline & & female & 14.1 & & female & 22.7 \\
\hline \multirow{2}{*}{ Doing research } & \multirow{2}{*}{56.5} & male & 32.6 & \multirow{2}{*}{59.1} & male & 27.2 \\
\hline & & female & 23.9 & & female & 31.8 \\
\hline \multirow{2}{*}{ Policy advisor/advocacy } & \multirow{2}{*}{19.6} & male & 15.2 & \multirow{2}{*}{11.3} & male & 4.5 \\
\hline & & female & 4.3 & & female & 6.8 \\
\hline \multirow{2}{*}{ Writing/editing/publishing } & \multirow{2}{*}{19.6} & male & 13 & \multirow{2}{*}{31.8} & male & 20.5 \\
\hline & & female & 6.5 & & female & 11.4 \\
\hline \multirow{2}{*}{ Managing } & \multirow{2}{*}{56.5} & male & 35.9 & \multirow{2}{*}{56.8} & male & 31.8 \\
\hline & & female & 20.7 & & female & 25 \\
\hline
\end{tabular}

Katherine Williams - Meiwita Budiharsana - Nguyen Thi Phuong Lan 
Research fellows' strongest skills are stratified by work sector to get a better understanding of who is benefiting most from HRDI activities and projects. Results are presented in Table 5 below, and it seems that returned fellows in different work sectors recount that they have different strongest skills. Yet, when analyzing the results, please take note of the small sample sizes in each of the categories, which may infer that any observed changes between the work sectors are not necessarily significant. Additionally, returned fellows indicated three strongest skills in both baseline and endline, therefore percentages do not add up to $100 \%$.

In reference to teaching and supervision as a strongest skill, more government employees indicated this as a strongest skill compared to non-government sector and self-employed/ students. In the endline, $65.6 \%$ of government employees indicated "teaching and supervision" as a strongest skill. "Doing research" was indicated to be a strongest skill by more self-employed and students and fewer non-government sector employees, in both baseline and endline. In the baseline, $100 \%$ of students and self-employed indicated research as one of their strongest skills, and in the endline $70.0 \%$ did so. As for policy advisory and advocacy, there did not seem to be any trend in the baseline data, yet in the endline survey, significantly more non-government employees indicated policy advocacy as a strongest skill $(21.1 \%)$ compared to government employees $(6.3 \%)$ and self-employed/ students (0\%). Writing, editing and publishing was considered a strongest skill by 31.8 percent of all endline respondents, yet did not seem to have a clear discrepancy between work sectors. "Managing," the final strongest skill, was considered their strongest skill by the majority on non-government employees in the baseline $(72.7 \%)$ and in the endline (63.2\%). Management was also identified as a "strongest skill" among government employees ( $50.0 \%$ in baseline and $62.5 \%$ in endline), and less so by self-employed and students (30.0\% in baseline and 33.3 percent in endline). 
Table 5: Strongest skills by work sector

\begin{tabular}{|c|c|c|c|c|c|c|c|c|c|c|}
\hline & \multicolumn{2}{|c|}{$\begin{array}{l}\text { Teaching/ } \\
\text { Supervision }\end{array}$} & \multicolumn{2}{|c|}{$\begin{array}{l}\text { Doing } \\
\text { Research }\end{array}$} & \multicolumn{2}{|c|}{$\begin{array}{c}\text { Policy } \\
\text { Advisor and } \\
\text { Advocacy }\end{array}$} & \multicolumn{2}{|c|}{$\begin{array}{l}\text { Writing/ } \\
\text { Editing/ } \\
\text { Publishing }\end{array}$} & \multicolumn{2}{|c|}{ Managing } \\
\hline \multicolumn{11}{|l|}{ Baseline $(n=92)$} \\
\hline Government $(n=48)$ & \multirow{3}{*}{$43.5 \%$} & $48.9 \%$ & \multirow{3}{*}{$56.5 \%$} & $58.3 \%$ & \multirow{3}{*}{$19.6 \%$} & $14.6 \%$ & \multirow{3}{*}{$19.6 \%$} & $20.8 \%$ & \multirow{3}{*}{$56.5 \%$} & $50.0 \%$ \\
\hline $\begin{array}{l}\text { Non-Government } \\
(n=33)\end{array}$ & & $43.9 \%$ & & $39.4 \%$ & & $24.2 \%$ & & $24.2 \%$ & & $72.7 \%$ \\
\hline $\begin{array}{l}\text { Student/Self-Employed } \\
(\mathrm{n}=10)\end{array}$ & & $30.0 \%$ & & $100.0 \%$ & & $30.0 \%$ & & $0.0 \%$ & & $30.0 \%$ \\
\hline \multicolumn{11}{|l|}{ Endline $(n=44)$} \\
\hline Government $(n=16)$ & \multirow{3}{*}{$58.0 \%$} & $65.6 \%$ & \multirow{3}{*}{$59.1 \%$} & $56.3 \%$ & \multirow{3}{*}{$11.3 \%$} & $6.3 \%$ & \multirow{3}{*}{$31.8 \%$} & $18.8 \%$ & \multirow{3}{*}{$56.8 \%$} & $62.5 \%$ \\
\hline $\begin{array}{l}\text { Non-Government } \\
(\mathrm{n}=19)\end{array}$ & & $57.9 \%$ & & $52.6 \%$ & & $21.1 \%$ & & $36.8 \%$ & & $63.2 \%$ \\
\hline $\begin{array}{l}\text { Student/Self-Employed } \\
(\mathrm{n}=9)\end{array}$ & & $44.4 \%$ & & $70.0 \%$ & & $0.0 \%$ & & $40.0 \%$ & & $33.3 \%$ \\
\hline
\end{tabular}

\subsection{Research and statistical methods skills}

The evaluation of research and statistical methods and skills included a comparison of the matching respondents from baseline and endline surveys, as any change in reported skills is best compared longitudinally. When asked about the level of competence in research during in the baseline survey, the majority of research fellows reported competence in both quantitative ( 84 percent) and qualitative ( 75 percent) research methods. Particular aspects of these research skills were further analyzed in the baseline and endline questionnaires.

As the HRDI program focused on improving research activities and development of participants as well as encouraging involvement in research within RF's individual professions, the extent of research methods and skills acquired in the program were of primary interest. Figure 7 below portrays the research methods that RFs report having in the baseline and the endline questionnaire. Results only include a sample size 
of 44 , including those participants who completed both the baseline and the endline questionnaires.

Figure 7: Returned fellows' research methods skills

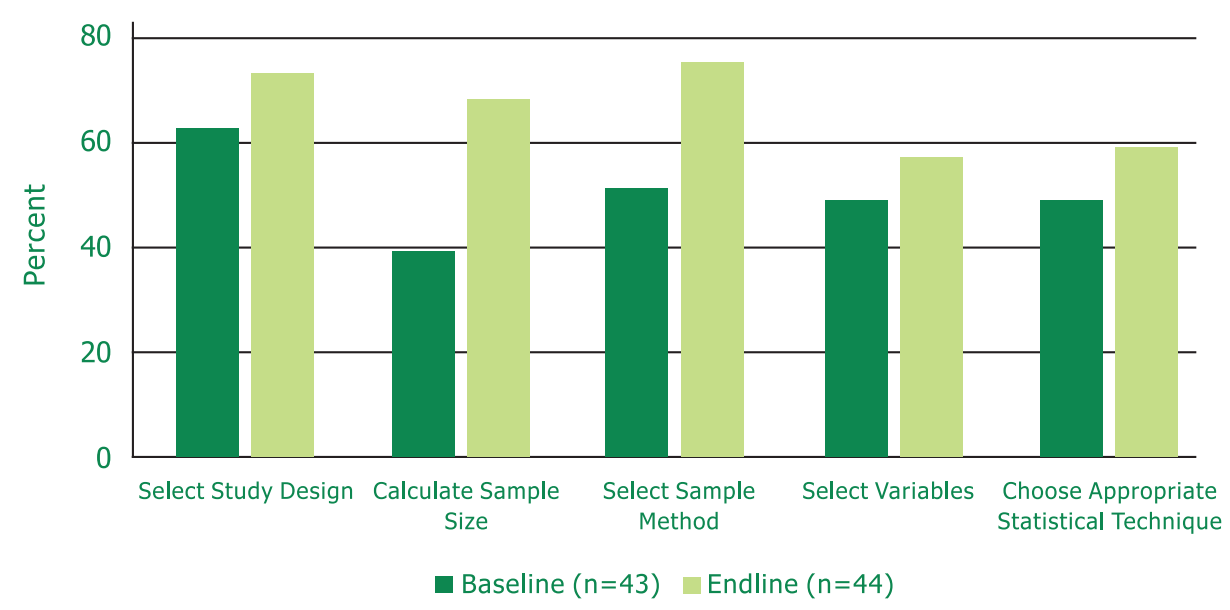

At baseline, 62.8 percent of returned fellows responding to the baseline questionnaire reported to be able to select a study design; 39.5 percent were able to calculate sample size; 51.2 percent able to select sample selection method, 48.8 percent select variables and 48.8 percent choose an appropriate statistical technique for their research. When a comparison of responses to baseline and endline studies is analyzed, the percentage of RFs reporting to be competent in particular research methods increases for every skill variable assessed. The most significant increases are seen in the skills of 1 ) calculating sample size (from 39.5 to 68.2) and 2) selecting sample method (from 51.2 to 75.0 percent). A chi-square test was conducted on the rates of reported research methods and skills, between baseline and endline questionnaires (displayed in Table 6). A statistically significant difference was noted in four of the five research methods evaluated: 1) select study design, 2) calculate sample size, 3) select sample method, and 4) choose appropriate statistical technique. These increases in research methods skills are likely indicative of the positive effect of the HRDI program at improving these particular skills and technical abilities in conducting research. The increases in these skills and technical abilities are likely utilized in returned fellows' current professional and research positions. 
Table 6: Returned fellows' research methods skills

\begin{tabular}{|c|c|c|c|c|c|}
\hline & \multicolumn{2}{|c|}{ Baseline $(n=43)$} & \multicolumn{2}{|c|}{ Endline $(n=44)$} & \multirow{2}{*}{$\begin{array}{c}\text { p } \\
\text { value }\end{array}$} \\
\hline & $n$ & percent & $\mathrm{n}$ & percent & \\
\hline Select Study Design & 27 & 62.8 & 32 & 72.7 & $<0.05$ \\
\hline Calculate Sample Size & 17 & 39.5 & 30 & 68.2 & $<0.01$ \\
\hline Select Sample Method & 22 & 51.2 & 33 & 75.0 & $<0.01$ \\
\hline Select Variables & 21 & 48.8 & 25 & 56.8 & 0.161 \\
\hline $\begin{array}{l}\text { Choose Appropriate Statistical } \\
\text { Technique }\end{array}$ & 21 & 48.8 & 26 & 59.1 & $<0.01$ \\
\hline
\end{tabular}

When interpreting the improvement in research methods abilities among RF in the HRDI program, it is pertinent to consider the maintenance of these skills. As can be seen in data presented earlier, many of the RFs are not working in the field of research and may not be utilizing these acquired skills frequently enough to maintain their aptitude. This may be a relevant focus for further replication and/or expansion of HRDI, providing refresher courses for Masters fellows and projects as well as activities for RFs to maintain these relevant and valuable technical skills.

Statistical skills can be particularly important for Masters fellows, as they are specialized and valuable, and may be required for particular research projects and/or positions. In addition to research methods and skills, statistical analysis methods-training was included in the HRDI program.

Analysis of returned fellows' competency in three statistical analysis methods does not demonstrate much of a difference between the baseline and endline surveys. As can be seen in Figure 8, the percentage of RFs who are able to use the particular statistical analysis skills only slightly change from baseline to endline questionnaires. Reported skills in multiple linear regressions decreased from 54 to 50 percent between baseline and endline; skills in logistic regression remained at 61 percent, and skills in stratified and cluster sampling slightly increase (from 26 to 30 percent) from baseline to endline surveys. 
Figure 8: Returned fellows' statistical methods and analysis skills

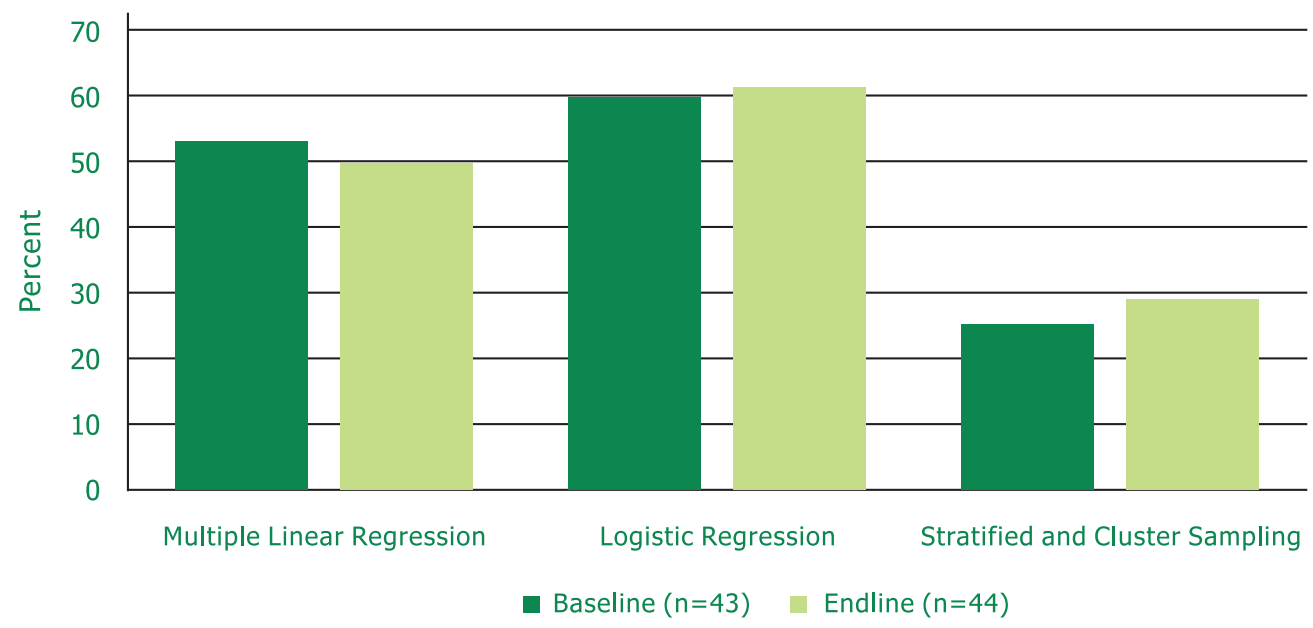

In terms of qualitative research skills, returned fellows reported qualitative research methods and skills they had in baseline and endline surveys. The sample size for this question included 40 respondents who answered the question in the baseline survey and the same 40 who provided a response in the endline survey. Respondents were asked to rank their skills in specific research methods, as "very good," "good," "neither good nor poor," "poor," or "very poor." Results presented in Figure 9 below present the percentage of respondents who indicated their skill as "good" or "very good". When asked about their ability to moderate focus group discussions or in-depth interviews, 33 of 40 RFs (82.5\%) indicated good or very good skills in baseline, and 30 of 40 said the same in endline. Ability to analyze qualitative data remained consistent between baseline and endline (27 of $40,67.5 \%$ ) and reports of good or very good skills in writing publications in both Vietnamese and in English declined from baseline to endline (52.5 to $45 \%$ and 23.1 to $20.5 \%$ respectively). 
Figure 9: Qualitative research methods and skills

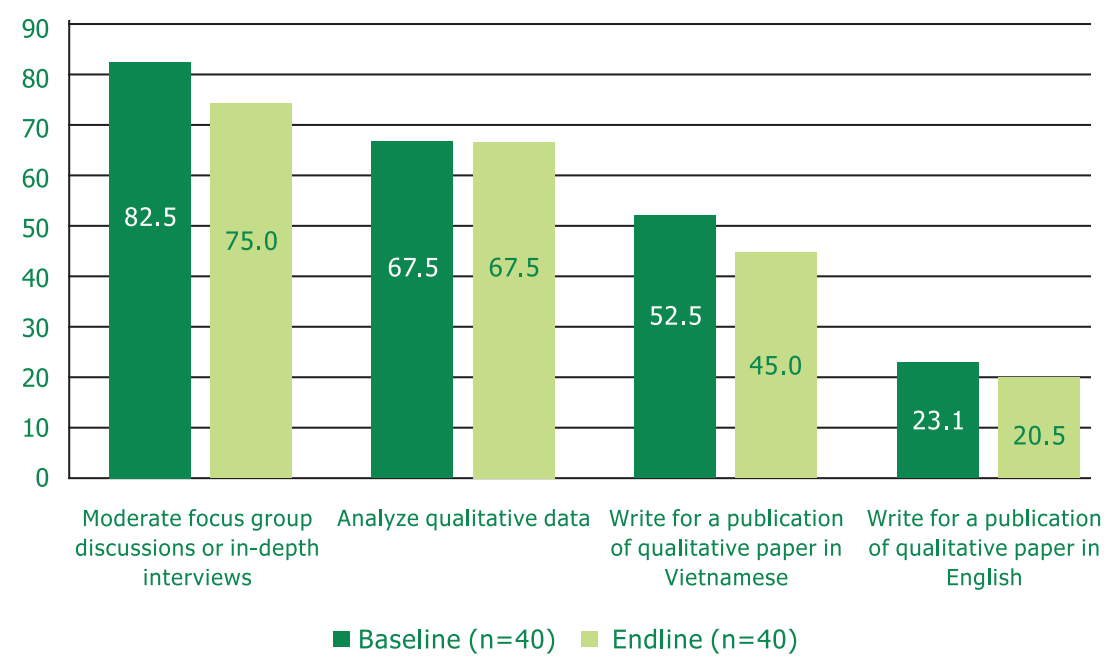

These results, more specifically declines, in qualitative skills may be attributed to returned fellows' lack of utilization of these research skills and the inevitable loss of these skills when not kept up and maintained. Anecdotal feedback from many returned fellows supported returned fellows' interest in qualitative research, yet as professions and job obligations do not allow for exercise of these skills, it is natural for RFs to lose them with time.

\subsection{Participation in research activities}

The impact evaluation of the HRDI program also included an assessment of whether returned fellows were conducting research after participation in the program, and what kind of research was taking place. Results are displayed in Figure 10 below. Among the 92 respondents who responded to the baseline questionnaire, 38 of them (41 percent) reported conducting research in the endline questionnaire. Four participants (4 percent) said that they were not currently conducting research, and 50 returned fellows (55 percent) were considered non-respondents, as they either did not return the endline survey or did not respond to that particular question. Of those who indicated that they 
were or had conducted research, over three-quarters reported conducting qualitative research and three-quarters reported conducting quantitative research.

Figure 10: Distribution of returned fellows who have conducted research

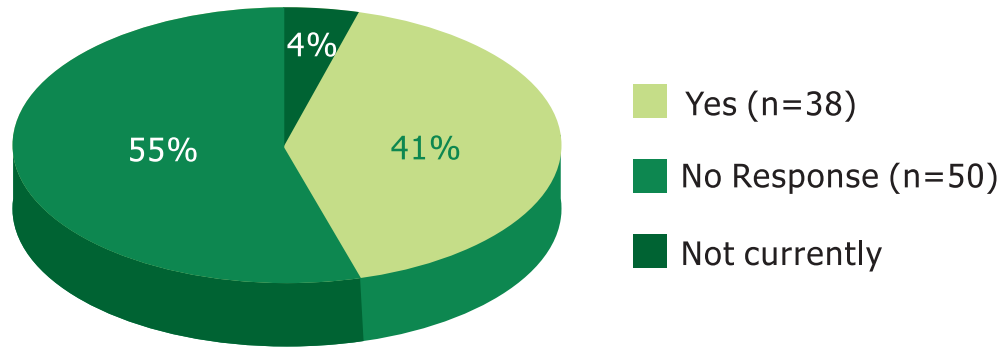

In addition to those who reported actually conducting research, a larger proportion of returned fellows, in both the baseline and the endline surveys, reported an interest in conducting research. This variable may be more representative of the effects of the HRDI program, as many returned fellows may be working in a current position and/ or trade that does not encourage and or facilitate research. The proportion of returned fellows who expressed interest in research at baseline was 91 percent. The proportion of returned fellows at endline with interest in research was 95 percent. Only a slight increase was observed between two surveys, yet the high percentage of RFs in both surveys exemplifies the overwhelming interest of these fellows to continue pursuing research degrees and/or participating in research projects and or professional positions.

The existence of plans to conduct one's own research project is another means to assess returned fellows' interest in conducting research as well as confidence in one's own ability. In the baseline assessment, 68 of the 92 respondents ( 74 percent) reported plans to conduct their own research. At endline, this proportion decreased to 64 percent (28 of 44) (data not shown). Plans to conduct research may change according to the extent of obligations and responsibilities at one's work, the flexibility within RF's current work for research activities, as well as the existence of resources and tools (such as statistical software) to conduct research within RF's current position. 
Figure 11: Timeline for conducting research

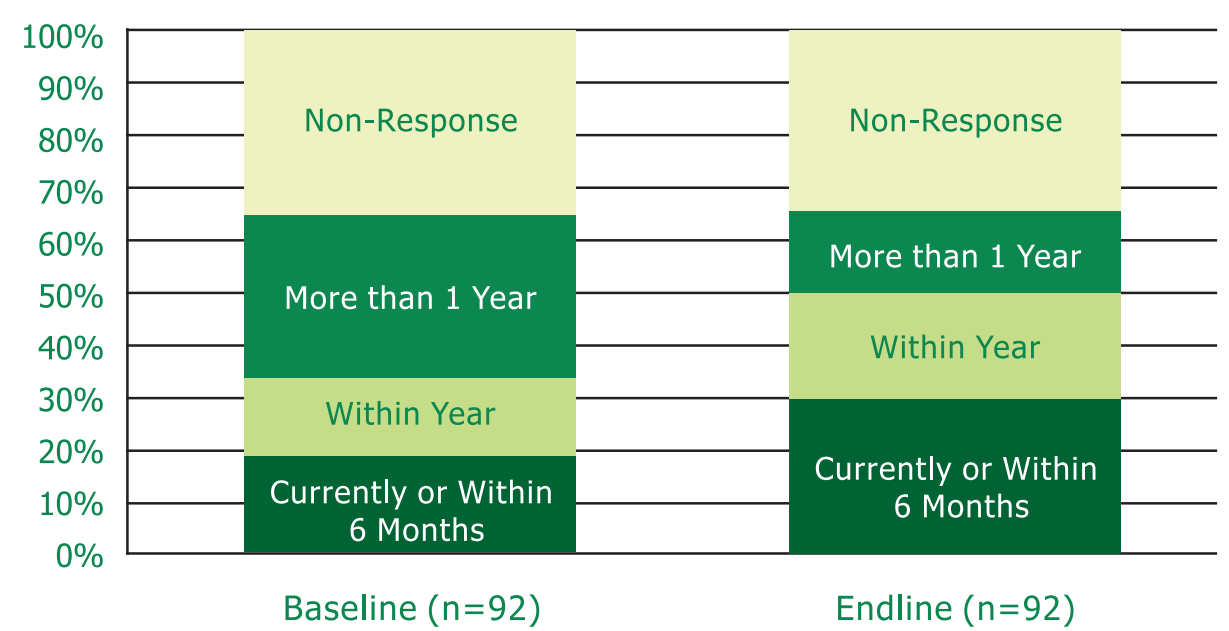

To further understand the intentions and plans to conduct research, evaluators inquired about the proposed timing of returned fellows' planned research. The majority of baseline respondents who planned to conduct research reported to have plans for this research in one year's time or later (28 percent). In comparison, only 16 percent of endline respondents indicated their research plans for one year's time or more. In contrast, returned fellows in the endline survey reported to have research plans much sooner: 30 percent were either already conducting research or had plans to its initiation in 6 months time (compared to 17 percent in baseline).

These differences in time frame for research may be indicative of differing job and/or school obligations between the times of the two surveys. Additionally, as respondents in the endline survey are three years older than they were in the baseline survey as well as further trained in research methods and potentially at higher professional grades than they were in baseline, the opportunities for research may be more prominent.

Returned fellows also have an opportunity to incorporate research skills and methods in their current positions, independent of whether they are conducting their own research project. Many of the research skills featured in the HRDI program are highly valued within 
the public health professional sector, and RFs may have a greater opportunity to advance within their current positions and/or take on new responsibilities or types of work by incorporating research and data skills in their professional portfolio.

In this regard, it is clear that participation in HRDI program has encouraged returned fellows to use research and data in their jobs and responsibilities. At the endline, 83 percent of returned fellows indicated that they used data and research findings in project management and implementation. In addition, 79 percent of returned fellows reported using data and research findings as evidence in setting priorities within their organization. These statistics represent the value that is put on research findings, evidence-base and scientific data and methods, after participation in the HRDI, a trait that may be considered one of the program's strong suits and important findings.

\subsection{Satisfaction with current job and job aspects}

Job satisfaction is of great importance to the HRDI program. Many of the fellows transitioned to new jobs and new fields after their fellowship experience, and a portion of fellows returned to school to pursue PhDs. Analysis of baseline and endline surveys shows an increase in satisfaction in four of the variables collected to represent returned fellows' overall professional satisfaction. Evaluation of job satisfaction included only the matching 44 returned fellows who completed both baseline and endline surveys, as satisfaction are a personally-interpretable variable and matching decreases the likelihood of sample variation.

The results in Figure 12 demonstrate a slight improvement in the percentage of returned fellows reporting satisfaction with their current job position (81 to 100 percent), their job content (91 to 95 percent), their opportunity to apply the skills obtained in graduate studies (77 to 86 percent), as well as the amount of support they received at their job for research activities (62 to 70 percent). Although only slight increases, the positive direction of each of these four variables may represent the benefits of participation in the HRDI program: with an expansion of skills and involvement in HRDI activities, returned fellows may be more active, participatory in their positions, or gain greater responsibility or authority with the gained experience and skills. 
When analyzing job satisfaction by work sector, for both baseline and endline surveys, there was no difference between satisfaction and work sector in either survey. Those in government and non-government sectors as well as students and others all reported similar rates of satisfaction with current position, content and other variables.

Figure 12: Returned fellows' satisfaction with current job and job aspects

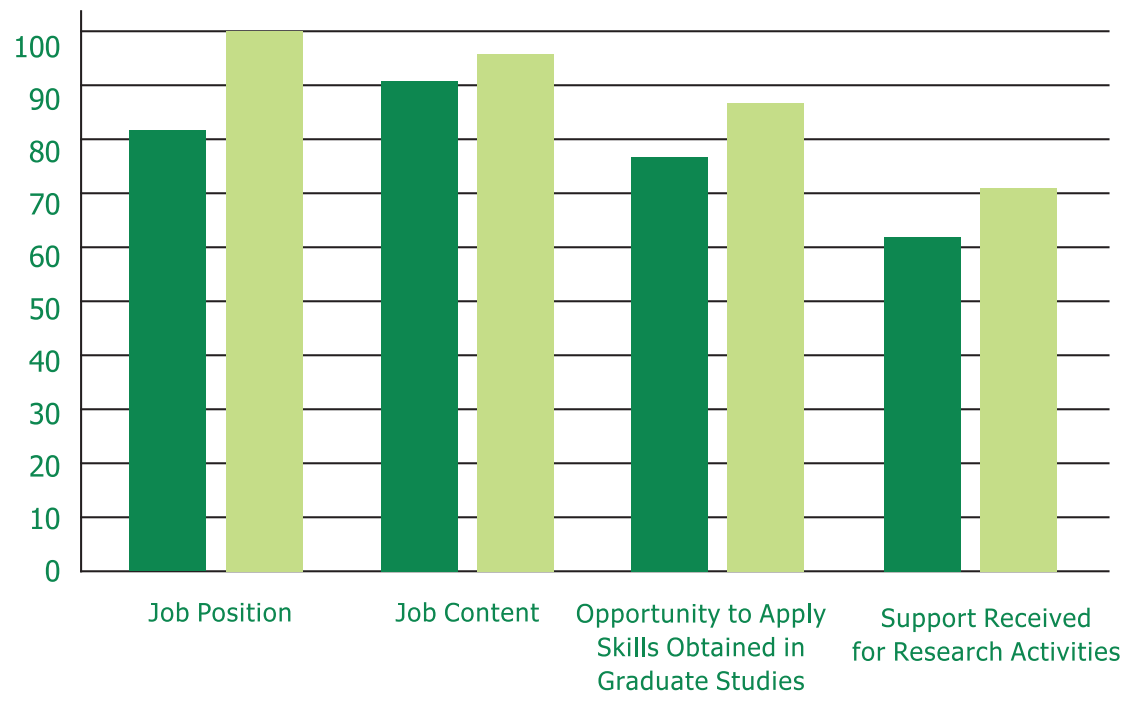

Baseline $(n=43) \quad$ Endline $(n=44)$ 
HRDI - Impact Evaluation Results 


\section{Conclusion}


This report provides information from baseline and endline surveys of returned fellows participating in the HRDI program in Viet Nam. Comparison in areas of type of work, job sector, research skills, participation in research studies and job satisfaction can be inferred from this data, yet in addition there are some barriers and limitations to the available data. Important potential limitations include: a few endline survey questions were changed after feedback from baseline surveys and a reassessment of the data of interest; and the very low response rate from the endline survey although the comparison of responders to non-responders demonstrates that there are no significant demographic differences between returned fellows who did and did not participate in the endline survey.

Analysis of the current position title and work status demonstrated that the numbers of RFs going into the government sector declined while positions in the non-government sector increased, likely due to differences in income-level. Additionally, the proportion of RFs indicating that their job titles included positions such as decision maker, planner, head and deputy in the baseline featured even more prominently in the endline, indicating that the HRDI program may be improving professional skills and increasing responsibilities. Important to note is the increased proportion of RFs pursuing a PhD after the HRDI program.

Within the particular job sectors, the analysis of RF's type of work demonstrated a slight movement from certain fields to others. The proportion of RFs working within the fields of service delivery and policy/advocacy tended to decline between baseline and endline, with movement towards training/teaching, management and research.

Returned fellows reported a number of skills to be "strongest skills", with most skills increasing between baseline and endline, particularly skills in teaching/supervision, doing research, and managing. These increases may signify a positive contribution of the HRDI program, as well as potential increases in confidence, stability and job responsibilities among returned fellows as time passes from baseline to endline surveys. There are few differences in these rates by gender. There are more significant differences in "acknowledged strongest skills" when stratified by work sector. More than 50 percent of all research fellows identified research as a strong skill, particularly those who were self-employed and students. Those working in the government sector felt particularly strong in fields of teaching/supervision as well as managing, in the endline survey. 
Non-government sector workers reported to thrive in writing/editing/publishing skills as well as slightly more than other sectors in publishing/advisor. Gearing further training and or participation towards returned fellows with a particular work sector may be of benefit in future programming.

The level of professional skills, in particular research and statistical methods and analyses, improved between baseline and endline surveys. The proportion of returned fellows reporting to have the following skills improved significantly: selecting study design, calculating sample size, selecting study method, and choosing appropriate statistical technique. The proportion of those able to select variables also improved yet was not statistically significant. These improvements in research skill-base are the crux of the HRDI impact.

Research skills, both quantitative and qualitative, must be practiced to be maintained. Results from the qualitative skills assessment demonstrated that many of these skills decline with participation in the HRDI program, and this is likely more a result of time than participation in the program. Anectodal evidence from the returned fellows complement this conclusion, as many admitted to not having the opportunity to use the research skills obtained in initial studies. Despite the expressed interest among nearly all RFs in participating in research projects, only a few fellows are keeping their skills up-to-date and active.

A majority of returned fellows report using data and research findings in current management and implementation of programs as well as in setting organizational priorities. Yet, these skills must be continuously utilized and regularly refreshed in order to be continuously applicable in current and future job positions. In addition to research skills and abilities, 41 percent of RFs reported actually conducting research and 64 percent report plans to conduct research in the near future.

With the results of the prospective evaluation in mind, recommendations from returned fellows were discussed at the Annual Scientific Meeting in November 2009. Twentyone attending returned fellows provided written feedback and recommendations. These recommendations included further training in certain research methods, such as statistical analysis, as well as assistance in writing research proposals. Another recommendation cited by 6 returned fellows was to strengthen the network between RFs and facilitate 
communication about topics of relevance and interest between them. Lastly, five returned fellows requested the formation of an advisory board to provide research mentoring and assistance with composition of research proposals and seeking funding.

These recommendations will be considered in the next phases of the HRDI program, yet many of the requests from the returned fellows are not feasible and/or cost-effective. Additionally, many of the requests were for program components that actually existed and were significantly underutilized within the implemented HRDI program-this includes the electronic network to connect returned fellows and statistical methods training.

Continuation and expansion of the HRDI program will require increased ownership from the Schools of Public Health participating in the fellowship program, more attention to the actual content of training programs, and more variety of survey research opportunities in Viet Nam. 


\section{Appendix}


50 HRDI - Impact Evaluation Results 

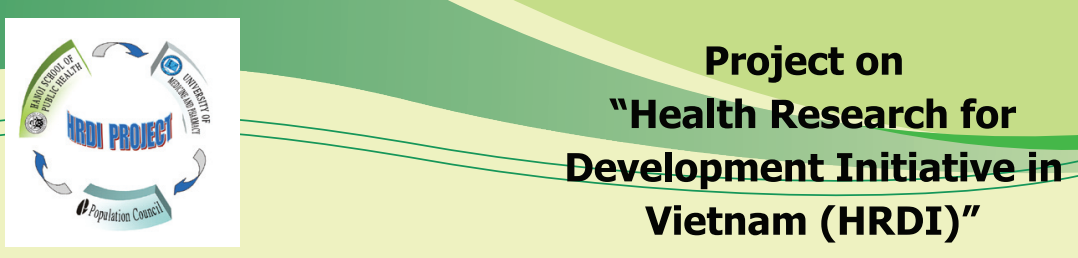

\section{Prospective Evaluation Survey Questionnaire}

The purpose of this survey is to find out about your professional experience since returning from a fellowship overseas, and about your participation in the Health Research for Development Initiative in Viet Nam (HRDI). This follows up on a Baseline Survey conducted in 2006.

The updated information provided through this questionnaire will help us to carefully evaluate the HRDI program, and assess its ability to assist returned fellows, maximize the use of acquired knowledge and skills, and foster professional development. We would be grateful for your open and honest feedback.

Please complete the questionnaire and return it by email, mail or fax on or before:

\section{$1^{\text {th }}$ August 2009}

Return to:

Nguyen Thi Phuong Lan Population Council, Viet Nam Office

41 Le Hong Phong, Ba Dinh

Ha Noi, Viet Nam

Tel: +84-4-3 734 5821/2/3/4/5/6

Fax: +84-4-3 7345827

ntplan@popcouncil.org

To answer the questionnaire, please fill in the blanks or place an " $X "$ next to the appropriate box.

It may speed completion of the section on professional experiences to have a current $\mathrm{CV}$ on hand to copy-paste relevant information. 


\section{A. PERSONAL INFORMATION}

\section{Please fill in the information below or check the appropriate response:}

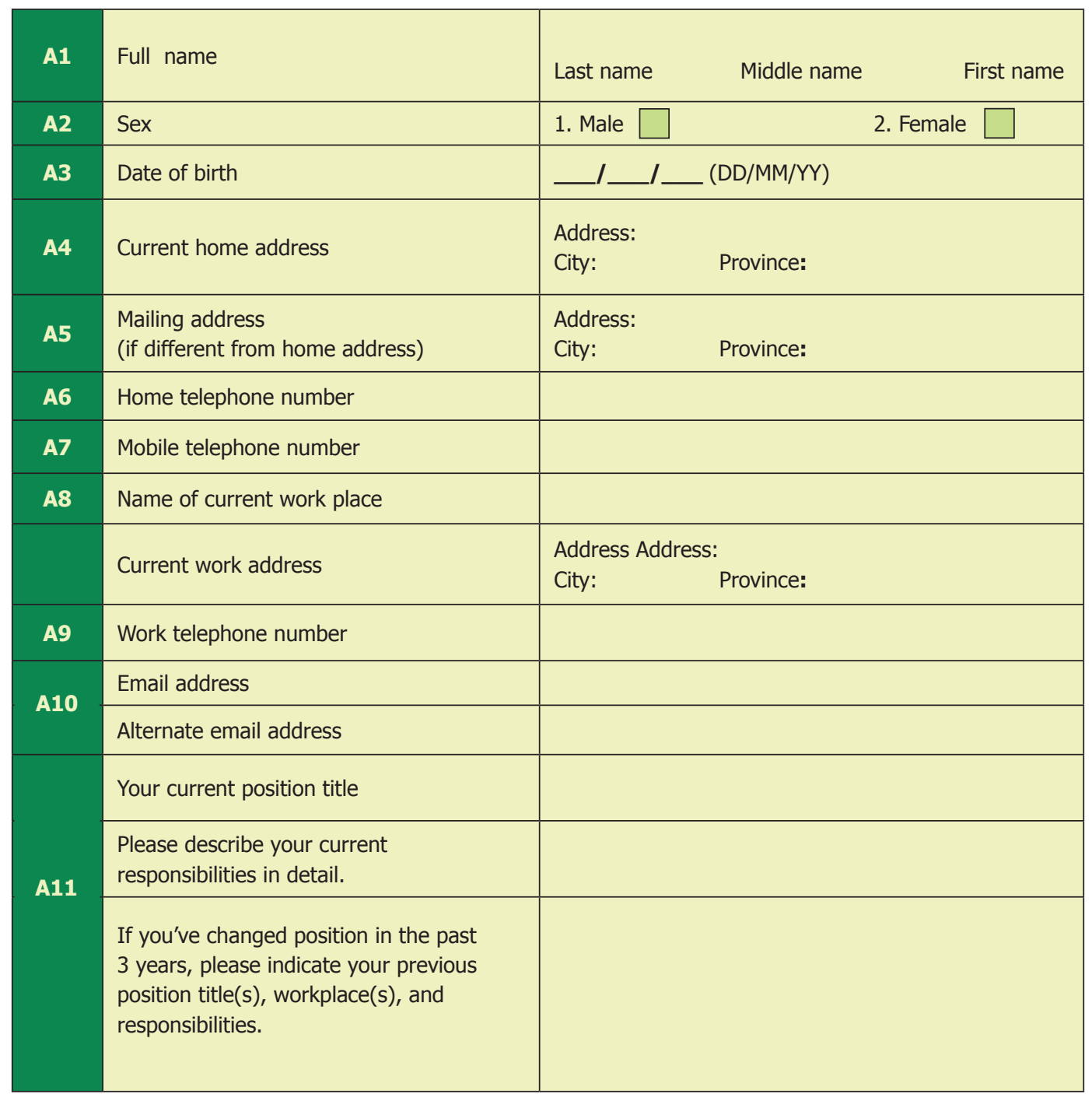




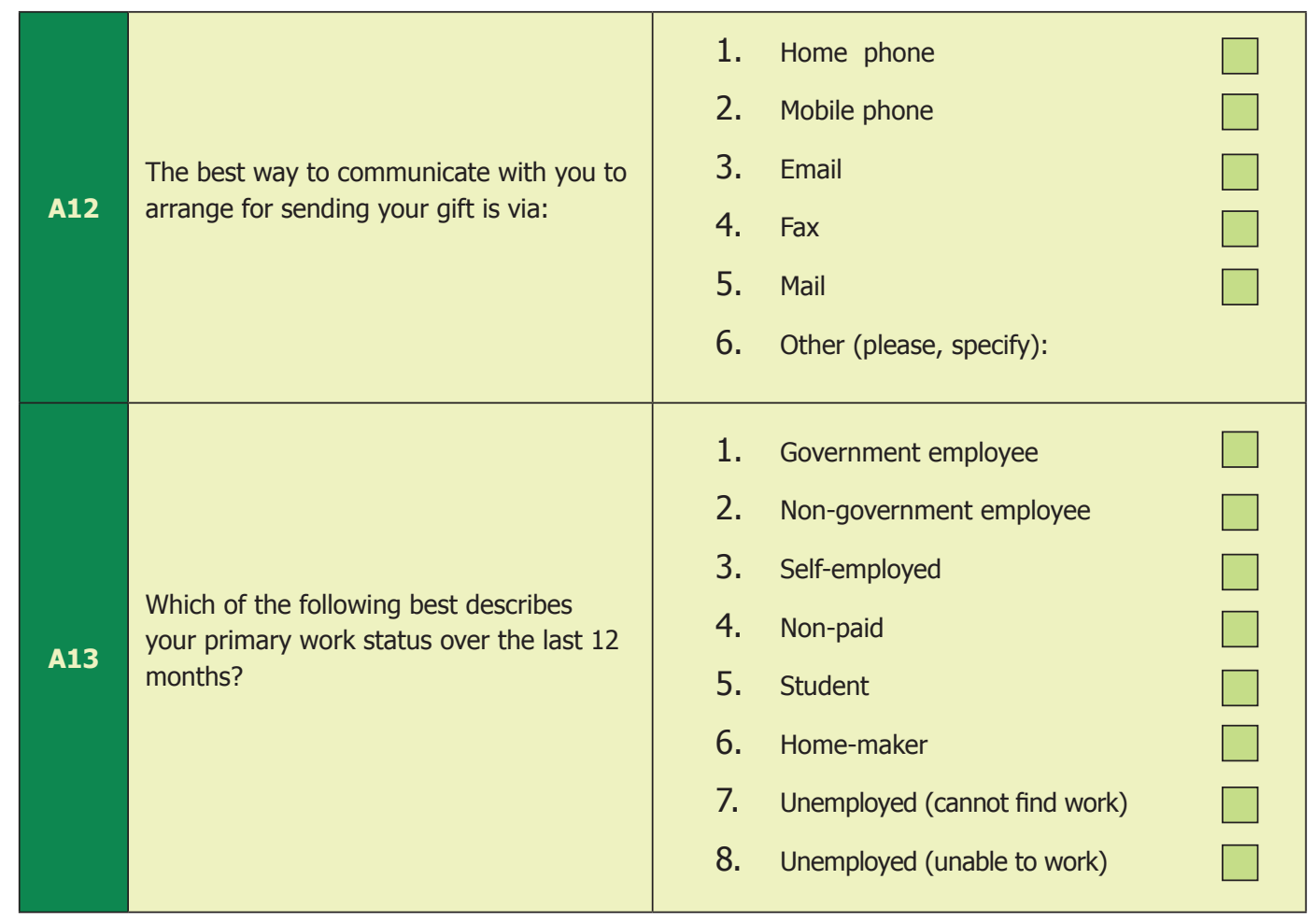

A14. In the table below, please indicate the degrees that you completed or are going to complete, year of graduation (or expected graduation), your field of study, and specialized areas of research.

\begin{tabular}{|l|l|l|l|l|}
\hline \multicolumn{1}{|c|}{ Degree } & Name and location of school & $\begin{array}{c}\text { Year } \\
\text { (graduated/ } \\
\text { expected) }\end{array}$ & $\begin{array}{c}\text { Field of } \\
\text { study }\end{array}$ & $\begin{array}{c}\text { Specialized } \\
\text { area(s) }\end{array}$ \\
\hline Master & & & & \\
\hline Doctorate & & & & \\
\hline $\begin{array}{l}\text { Other } \\
\text { (specify) }\end{array}$ & & & & \\
\hline
\end{tabular}


A15. In the table below, please specify the title of any thesis or dissertation completed.

\begin{tabular}{|l|l|}
\hline \multicolumn{1}{|c|}{ Degree } & \multicolumn{1}{c|}{ Title of your thesis } \\
\hline Master & \\
\hline Doctorate & \\
\hline Other & \\
\hline
\end{tabular}

A16. Which of the following types of work do you do in your current position (select all that apply)

1. Service delivery

2. Training/teaching

3. Research

4. Policy/advocacy

5. Consultancy

6. Other (please specify):

A17. Which of the following is the primary type of work you do in your current position?

1. Service delivery

2. Training/teaching

3. Research

4. Policy/advocacy

5. Consultancy

6. Other (please specify): 
A18. How frequently do you use the following skills in your work?

\begin{tabular}{|l|r|r|r|r|}
\hline & $\begin{array}{c}\text { Very } \\
\text { frequently }\end{array}$ & Frequently & $\begin{array}{c}\text { Not } \\
\text { frequently }\end{array}$ & \multicolumn{2}{c|}{ Not at all } \\
\hline Presentation & $\square$ & $\square$ & $\square$ & $\square$ \\
\hline Research & $\square$ & $\square$ & $\square$ & $\square$ \\
\hline Supervision & $\square$ & $\square$ & $\square$ & $\square$ \\
\hline Teaching & $\square$ & $\square$ & $\square$ & \\
\hline Project management & $\square$ & $\square$ & $\square$ & \\
\hline Writing proposal & $\square$ & $\square$ & $\square$ & $\square$ \\
\hline Other: & $\square$ & $\square$ & $\square$ & $\square$ \\
\hline
\end{tabular}




\section{B. PROFESSIONAL EXPERIENCES POST-FELLOWSHIP}

Please complete the following information. It may speed completion of the section to have a current $\mathrm{CV}$ available to copy-paste relevant information. You may add rows to the table if required.

B1. Please list all teaching experience(s) you have had since completing your Master's degree.

\begin{tabular}{|c|c|c|c|c|}
\hline $\begin{array}{c}\text { Dates } \\
\mathrm{MM} / \mathrm{YY}- \\
\mathrm{MM} / \mathrm{YY}\end{array}$ & Name of course & Location/Institution & $\begin{array}{c}\text { Student } \\
\text { level }\end{array}$ & Class size \\
\hline & & & & \\
\hline & & & & \\
\hline & & & & \\
\hline & & & & \\
\hline
\end{tabular}

Have you learned any new skills as a result of this/these experience(s)? If so, please describe:

B2. Please list all research experience(s) you have had since completing your Master's degree.

\begin{tabular}{|c|c|c|c|c|}
\hline $\begin{array}{c}\text { Dates } \\
\mathrm{MM} / \mathrm{YY}- \\
\mathrm{MM} / \mathrm{YY}\end{array}$ & Name and location of study & $\begin{array}{c}\text { Funding } \\
\text { source(s) }\end{array}$ & $\begin{array}{c}\text { Your responsibilities } \\
\text { (e.g. data collection, analysis, } \\
\text { interpretation, report writing) }\end{array}$ & $\begin{array}{c}\text { Product(s)* } \\
\text { (e.g. reports, } \\
\text { articles) }\end{array}$ \\
\hline & & & & \\
\hline & & & & \\
\hline & & & & \\
\hline & & & & \\
\hline
\end{tabular}

Have you learned any new skills as a result of this/these experience(s)? If so, please describe:

*For each product, please provide complete information in Question B9 
B3. Please list any supervision/management experience(s) since completing your Master's degree.

\begin{tabular}{|l|l|l|l|}
\hline $\begin{array}{c}\text { Dates } \\
\mathrm{MM} / \mathrm{YY}- \\
\mathrm{MM} / \mathrm{YY}\end{array}$ & Title of position & $\begin{array}{c}\text { Location/ } \\
\text { Institution }\end{array}$ & $\begin{array}{c}\text { \# staff you } \\
\text { supervise }\end{array}$ \\
\hline & & & \\
\hline & & & \\
\hline & & & \\
\hline & & & \\
\hline
\end{tabular}

Have you learned any new skills as a result of this/these experience(s)? If so, please describe:

B4. Please list any experiences in project implementation since completing your Master's degree.

\begin{tabular}{|c|c|c|c|c|c|}
\hline $\begin{array}{l}\text { Dates } \\
\text { MM/YY- } \\
\text { MM/YY }\end{array}$ & Title of project & $\begin{array}{c}\text { Scope } \\
\text { (local, national, } \\
\text { international) }\end{array}$ & $\begin{array}{c}\text { Your role in this } \\
\text { project }\end{array}$ & $\begin{array}{l}\text { Funding } \\
\text { source(s) }\end{array}$ & $\begin{array}{c}\text { Budget } \\
\text { amount } \\
\text { (USD) }\end{array}$ \\
\hline & & & & & \\
\hline & & & & & \\
\hline & & & & & \\
\hline & & & & & \\
\hline
\end{tabular}

Have you learned any new skills as a result of this/these experience(s)? If so, please describe: 
B5. Please tell us about your experience(s) in any of the areas listed below since completing your Master's degree.

\begin{tabular}{|l|c|c|c|c|c|}
\hline Area & Weekly & Monthly & Yearly & Never & Please describe \\
\hline Served on committee & $\square$ & $\square$ & $\square$ & $\square$ & \\
\hline Interviewed as expert & $\square$ & $\square$ & $\square$ & $\square$ & \\
\hline Being a policy advisor/advocator & $\square$ & $\square$ & $\square$ & $\square$ & \\
\hline Wrote proposal & $\square$ & $\square$ & $\square$ & $\square$ & \\
\hline Acted as a consultant & $\square$ & $\square$ & $\square$ & $\square$ & \\
\hline
\end{tabular}

B6. Please list any conferences at which you have presented paper(s) or posters since completing your Master's degree.

\begin{tabular}{|c|l|l|l|l|l|}
\hline $\begin{array}{c}\text { Date } \\
\text { (MM/YY) }\end{array}$ & Name of Conference & Location & $\begin{array}{c}\text { Type } \\
\text { (oral, poster, invited) }\end{array}$ & Title & $\begin{array}{c}\text { Source } \\
\text { of travel } \\
\text { fund }\end{array}$ \\
\hline & & & & & \\
\hline & & & & & \\
\hline & & & & & \\
\hline & & & & & \\
\hline
\end{tabular}

B7. Please list any training courses ( $>4$ days) you have attended since completing your Master's degree.

\begin{tabular}{|l|l|l|l|l|}
\hline $\begin{array}{c}\text { Date } \\
(\mathrm{DD}-\mathrm{DD} / \mathrm{MM} / \mathrm{YY})\end{array}$ & Name of course & $\begin{array}{c}\text { Sponsoring } \\
\text { organization }\end{array}$ & Location & Content of training \\
\hline & & & & \\
\hline & & & & \\
\hline & & & & \\
\hline & & & & \\
\hline
\end{tabular}

Katherine Williams - Meiwita Budiharsana - Nguyen Thi Phuong Lan 
B8. Please list the professional associations/networks in which you are or have been a member since completing your Master's degree.

\begin{tabular}{|l|l|l|}
\hline $\begin{array}{c}\text { Dates } \\
(\mathrm{MM} / \mathrm{YY}-\mathrm{MM} / \mathrm{YY})\end{array}$ & Name of Professional Association/Network & Title/Role (if applicable) \\
\hline & & \\
\hline & & \\
\hline & & \\
\hline & & \\
\hline
\end{tabular}

B9. Please list any publication(s) you have been author(s) or co-author(s) for, since completing your Master's degree.

\begin{tabular}{|l|l|}
\hline Compete citation or website address & $\begin{array}{c}\text { Product type } \\
\text { (e.g. book, book chapter, peer-reviewed } \\
\text { article, website material) }\end{array}$ \\
\hline & \\
\hline & \\
\hline & \\
\hline & \\
\hline & \\
\hline
\end{tabular}




\section{SITUATION ANALYSIS}

\section{Please fill in the information, or check the desired response}

C1. What do you think about your present situation? Please check the appropriate box for each aspect.

\begin{tabular}{|l|c|c|c|c|}
\hline & $\begin{array}{c}\text { Very } \\
\text { satisfied }\end{array}$ & Satisfied & $\begin{array}{c}\text { Not } \\
\text { satisfied }\end{array}$ & $\begin{array}{c}\text { No } \\
\text { answer } \\
\text { or NA }\end{array}$ \\
\hline Your position & $\square$ & $\square$ & $\square$ & $\square$ \\
\hline Your job's content & $\square$ & $\square$ & $\square$ & $\square$ \\
\hline Your workload & $\square$ & $\square$ & $\square$ & $\square$ \\
\hline Your colleagues & $\square$ & $\square$ & $\square$ & $\square$ \\
\hline Your professional future in this workplace & $\square$ & $\square$ & $\square$ & $\square$ \\
\hline $\begin{array}{l}\text { Your relations with your supervisor or higher } \\
\text { officials }\end{array}$ & $\square$ & $\square$ & $\square$ & $\square$ \\
\hline $\begin{array}{l}\text { The opportunity to apply skills that you obtained } \\
\text { in your graduate study }\end{array}$ & $\square$ & $\square$ & $\square$ & $\square$ \\
\hline $\begin{array}{l}\text { Your ability to keep up-to-date with current } \\
\text { knowledge in your field }\end{array}$ & $\square$ & $\square$ & $\square$ & $\square$ \\
\hline $\begin{array}{l}\text { Your ability to use English in your professional } \\
\text { activities }\end{array}$ & $\square$ & $\square$ & $\square$ & $\square$ \\
\hline Support for research activities & $\square$ & $\square$ & $\square$ & $\square$ \\
\hline Other: & $\square$ & $\square$ & $\square$ & $\square$ \\
\hline
\end{tabular}


C2. At present, what do you think are your strongest skills? Please rank the following options.

Teaching
Supervising
Doing research
Policy advisor/advocacy
Writing/Editing/Publishing
Managing project(s)
Other (please specify):

C3. What are your professional goals in coming 5 years? Please rank the following options:

__ Improving my performance in my present job Getting a promotion in my current place of employment

__ Getting another degree(s). Please specify degree and field of study:

__ Getting more training course(s). Please specify area:

__ Doing research. Please specify topic:

_ Improving program/project management skills

__ Writing/publishing books/articles

___ Providing clinical and/or other client services

__ Searching for another job

Other:

Please explain your choices: 


\begin{tabular}{|c|c|c|}
\hline C4 & $\begin{array}{l}\text { Have you done research since } \\
\text { completing your master's? }\end{array}$ & 1. Yes $\square$ \\
\hline C5 & If yes, what type of research? & $\begin{array}{l}\text { 1. Qualitative research } \\
\text { 2. Quantitative research } \\
\text { 3. Other: }\end{array}$ \\
\hline C6 & $\begin{array}{l}\text { What stage(s) in the research } \\
\text { cycle do you have experience } \\
\text { in? } \\
\text { You may select more than } \\
\text { one option. }\end{array}$ & $\begin{array}{l}\text { 1. Design research protocol } \\
\text { 2. Sampling and develop research instruments } \\
\text { 3. Conduct training and supervise data collectioprocess } \\
\text { 4. Analyze data } \\
\text { 5. Writing up report } \\
\text { 6. Present report } \\
\text { 7. Writing for publication }\end{array}$ \\
\hline C7 & $\begin{array}{l}\text { If you have not done research } \\
\text { since completing your master's, } \\
\text { please indicate why not: } \\
\text { You may select more than } \\
\text { one option. }\end{array}$ & $\begin{array}{l}\text { 1. Cannot find funding } \\
\text { 2. Have no time } \\
\text { 3. Cannot find the right topics } \\
\text { 4. Not enough knowledge in doing research } \\
\text { 5. Your supervisor will not allow it } \\
\text { 6. Other: }\end{array}$ \\
\hline C8 & $\begin{array}{l}\text { Do you hope to be involved } \\
\text { more in doing research in the } \\
\text { future? }\end{array}$ & 1. Yes $\square$ \\
\hline
\end{tabular}




\begin{tabular}{|c|c|c|}
\hline $\mathbf{C O}$ & $\begin{array}{l}\text { Select the stage(s) in the } \\
\text { research cycle that you } \\
\text { would like to be involved in. } \\
\text { You may select more } \\
\text { than one option. }\end{array}$ & $\begin{array}{l}\text { 1. Design research protocol } \\
\text { 2. Sampling and develop research instruments } \\
\text { 3. Conduct training and supervise data collection } \\
\text { process } \\
\text { 4. Analyze data } \\
\text { 5. Writing up report } \\
\text { 6. Present report } \\
\text { 7. Writing for publication }\end{array}$ \\
\hline C10 & $\begin{array}{l}\text { Do you plan to do your own } \\
\text { research project? }\end{array}$ & 1. Yes $\square$ \\
\hline C11 & $\begin{array}{l}\text { When do you plan to do } \\
\text { your own research project? }\end{array}$ & $\begin{array}{l}\text { 1. Within the next six months } \\
\text { 2. Within the next year } \\
\text { 3. In more than a year's time }\end{array}$ \\
\hline C12 & $\begin{array}{l}\text { What topic(s) are you } \\
\text { interested in doing research } \\
\text { on? }\end{array}$ & \\
\hline
\end{tabular}

C13. Do you use data and/or research findings as evidence in project management and implementation?
1. Yes
2. No
If yes, please provide an example: 
C14. Do you use data and/or research findings as evidence to set priorities in your organization?
1. Yes
2. No
If yes, please provide an example:

C15. Is use of data and/or research findings as evidence common practice throughout your organization?
1. Yes
2. No
Please explain:

C16. If no to C15, do you think thing there is a need for this within your organization? Why/why not

C17. What is your supervisor or coworker's attitudes toward using research-based evidence in the decision-making process at your work place? 


\begin{tabular}{|c|c|c|c|c|c|}
\hline \multicolumn{6}{|l|}{ C18. Please rate your skills in doing research. } \\
\hline & $\begin{array}{l}\text { Very } \\
\text { good }\end{array}$ & Good & $\begin{array}{l}\text { Neither } \\
\text { good } \\
\text { nor } \\
\text { poor }\end{array}$ & Poor & $\begin{array}{l}\text { Very } \\
\text { poor }\end{array}$ \\
\hline 1. Identifying research problems/questions & [ & L & $\square$ & [ & \\
\hline 2. Prioritizing research problems/questions & & & $\square$ & - & \\
\hline 3. Analyzing research problems/questions & & 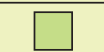 & $\square$ & 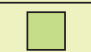 & L \\
\hline 4. Writing a research proposal & & 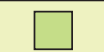 & $\square$ & L & 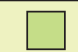 \\
\hline 5. Finding information using the internet & [ & L & $\square$ & L & L \\
\hline 6. Conducting a formal review of academic literature & & & $\square$ & L & \\
\hline 7. Managing reference materials & & & $\square$ & 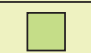 & $\square$ \\
\hline $\begin{array}{l}\text { 8. Training and supervision for data collection in quantitative } \\
\text { research }\end{array}$ & & & $\square$ & L & L \\
\hline $\begin{array}{l}\text { 9. Conducting a focus group discussion or in-depth } \\
\text { interview }\end{array}$ & & & L & L & \\
\hline 10. Descriptive statistics and simple quantitative analysis & & & $\square$ & L & L \\
\hline 11. Analyzing qualitative data & & & $\square$ & $\square$ & $\square$ \\
\hline $\begin{array}{l}\text { 12. Writing for publication of a quantitative paper in } \\
\text { Vietnamese }\end{array}$ & & & $\square$ & L & $\square$ \\
\hline 13. Writing for publication of a quantitative paper in English & & 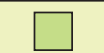 & $\square$ & L & $\square$ \\
\hline $\begin{array}{l}\text { 14. Writing for publication of a qualitative paper in } \\
\text { Vietnamese }\end{array}$ & 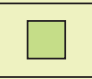 & $\Gamma$ & $\square$ & $\square$ & $\square$ \\
\hline 15. Writing for publication of a qualitative paper in English & L & \begin{tabular}{|r} 
\\
\end{tabular} & $\square$ & $\square$ & $\square$ \\
\hline 16. Designing a project & L & $\square$ & $\square$ & $\square$ & $\square$ \\
\hline 17. Implementing a project & $\square$ & $\square$ & $\square$ & $\square$ & $\square$ \\
\hline 18. Evaluating a project & $\square$ & $\square$ & $\square$ & $\square$ & $\square$ \\
\hline
\end{tabular}




\begin{tabular}{|c|c|c|}
\hline C19 & $\begin{array}{l}\text { Which of the following } \\
\text { skills in intermediate } \\
\text { analytical statistics do } \\
\text { you have? }\end{array}$ & $\begin{array}{l}\text { 1. Stratification } \\
\text { 2. Multiple linear regression } \\
\text { 3. Logistic regression } \\
\text { 4. Other: }\end{array}$ \\
\hline C20 & $\begin{array}{l}\text { Which of the following } \\
\text { skills in advanced } \\
\text { analytical statistics do } \\
\text { you have? }\end{array}$ & $\begin{array}{l}\text { 1. Effect modification } \\
\text { 2. Survival Analysis } \\
\text { 3. Time series } \\
\text { 4. Analysis for stratified and cluster sampling design } \\
\text { 5. Other: }\end{array}$ \\
\hline C21 & $\begin{array}{l}\text { Which of the following } \\
\text { skills in research methods } \\
\text { do you have? }\end{array}$ & $\begin{array}{l}\text { 1. Select study design } \\
\text { 2. Calculating sample size } \\
\text { 3. Select sampling method } \\
\text { 4. Select variables } \\
\text { 5. Choose appropriate statistical techniques } \\
\text { 6. Choose appropriate qualitative techniques }\end{array}$ \\
\hline
\end{tabular}

C22. Please let us know in which areas you think your skills need to be improved: 


\section{HRDI ACTIVITIES AND YOUR PARTICIPATION}

We would appreciate your open and honest feedback about HRDI activities.

D1. Please, let us know how you learned about HRDI program and its activities. Select all that apply.

\begin{tabular}{|l|c|c|c|c|c|c|c|}
\multicolumn{1}{|c|}{ Activities } & $\begin{array}{c}\text { Returned } \\
\text { fellows } \\
\text { network }\end{array}$ & $\begin{array}{l}\text { Email/ } \\
\text { Listlink }\end{array}$ & $\begin{array}{c}\text { HRDI } \\
\text { Website }\end{array}$ & Brochure & $\begin{array}{c}\text { HRDI } \\
\text { partners }\end{array}$ & $\begin{array}{c}\text { Other } \\
\text { (specify) }\end{array}$ & $\begin{array}{c}\text { Unaware } \\
\text { up to } \\
\text { this } \\
\text { point }\end{array}$ \\
\hline HRDI program & $\square$ & $\square$ & $\square$ & $\square$ & $\square$ & $\square$ & $\square$ \\
\hline Short course & $\square$ & $\square$ & $\square$ & $\square$ & $\square$ & $\square$ & $\square$ \\
\hline Teaching placement & $\square$ & $\square$ & $\square$ & $\square$ & $\square$ & $\square$ & $\square$ \\
\hline Research placement & $\square$ & $\square$ & $\square$ & $\square$ & $\square$ & $\square$ & $\square$ \\
\hline Small research grant & $\square$ & $\square$ & $\square$ & $\square$ & $\square$ & $\square$ & $\square$ \\
\hline Post-activity tutoring & $\square$ & $\square$ & $\square$ & $\square$ & $\square$ & $\square$ & $\square$ \\
\hline $\begin{array}{l}\text { Professional } \\
\text { Development Award }\end{array}$ & $\square$ & $\square$ & $\square$ & $\square$ & $\square$ & $\square$ & $\square$ \\
\hline $\begin{array}{l}\text { Course on writing and } \\
\text { presentation skills }\end{array}$ & $\square$ & $\square$ & $\square$ & $\square$ & $\square$ & $\square$ & $\square$ \\
\hline $\begin{array}{l}\text { Annual scientific } \\
\text { meeting }\end{array}$ & $\square$ & $\square$ & $\square$ & $\square$ & $\square$ & $\square$ & $\square$ \\
\hline HRDI listlink & $\square$ & $\square$ & $\square$ & $\square$ & $\square$ & $\square$ & $\square$ \\
\hline HRDI website & $\square$ & $\square$ & $\square$ & $\square$ & $\square$ & $\square$ & $\square$ \\
\hline HRDI newsletter & $\square$ & $\square$ & $\square$ & $\square$ & $\square$ & $\square$ & $\square$ \\
\hline $\begin{array}{l}\text { Technical assistance in } \\
\text { writing for publication }\end{array}$ & $\square$ & $\square$ & $\square$ & $\square$ & $\square$ & $\square$ & $\square$ \\
\hline
\end{tabular}


D2. Which HRDI activities have you participated in?

\begin{tabular}{|l|c|l|}
\hline \multicolumn{2}{|c|}{ Activity Participated? } & \multicolumn{2}{c|}{ If you have not participated, why not? } \\
\hline Short course & $\square$ & \\
\hline Teaching placement & $\square$ & \\
\hline Research placement & $\square$ & \\
\hline Small research grant & $\square$ & \\
\hline Post-activity tutoring & $\square$ & \\
\hline Professional development award & $\square$ & \\
\hline $\begin{array}{l}\text { Course on writing and presentation } \\
\text { skills }\end{array}$ & $\square$ & \\
\hline Annual scientific meeting & $\square$ & \\
\hline HRDI listlink & $\square$ & \\
\hline HRDI website & $\square$ & \\
\hline HRDI Newsletter & $\square$ & \\
\hline TA in writing for publication & $\square$ & \\
\hline
\end{tabular}

D3. In general, what prevented you from participating HRDI activities?

1. Not interested in content

2. Competitive process

3. Time conflict

4. Distance/transport/logistics

5. Your supervisor does not support it

6. Other: 
D4. Please, let us know how you rate HRDI program by checking the appropriate box. Please only rate those activities you have participated in.

\begin{tabular}{|l|c|c|c|c|c|c|}
\hline \multicolumn{1}{|c|}{ Activities } & $\begin{array}{c}\text { Very } \\
\text { good }\end{array}$ & Good & $\begin{array}{c}\text { Neither } \\
\text { good } \\
\text { nor } \\
\text { poor }\end{array}$ & Poor & $\begin{array}{l}\text { Very } \\
\text { poor }\end{array}$ & Comments \\
\hline Short course & $\square$ & $\square$ & $\square$ & $\square$ & $\square$ & \\
\hline Teaching placement & $\square$ & $\square$ & $\square$ & $\square$ & $\square$ & \\
\hline Research placement & $\square$ & $\square$ & $\square$ & $\square$ & $\square$ & \\
\hline Small Research Grant & $\square$ & $\square$ & $\square$ & $\square$ & $\square$ & \\
\hline Post-activity tutoring & $\square$ & $\square$ & $\square$ & $\square$ & $\square$ & \\
\hline $\begin{array}{l}\text { Professional Development } \\
\text { award }\end{array}$ & $\square$ & $\square$ & $\square$ & $\square$ & $\square$ & \\
\hline $\begin{array}{l}\text { Course on Writing and } \\
\text { presentation skills }\end{array}$ & $\square$ & $\square$ & $\square$ & $\square$ & $\square$ & \\
\hline Annual Scientific Meeting & $\square$ & $\square$ & $\square$ & $\square$ & $\square$ & \\
\hline HRDI listlink & $\square$ & $\square$ & $\square$ & $\square$ & $\square$ & \\
\hline HRDI website & $\square$ & $\square$ & $\square$ & $\square$ & $\square$ & \\
\hline HRDI Newsletter & $\square$ & $\square$ & $\square$ & $\square$ & $\square$ & \\
\hline TA in writing for publication & $\square$ & $\square$ & $\square$ & $\square$ & $\square$ & \\
\hline
\end{tabular}

D5. Which aspect of each activity do you should be improved or modified in order to better meet RF needs? Please, be as specific as possible using the table below.

\begin{tabular}{|l|c|c|c|c|c|c|}
\hline \multicolumn{1}{|c|}{ Activities } & Content & $\begin{array}{c}\text { Procedure/ } \\
\text { Administration }\end{array}$ & Duration & $\begin{array}{c}\text { Deadline/ } \\
\text { application } \\
\text { process }\end{array}$ & $\begin{array}{c}\text { Not a } \\
\text { useful } \\
\text { activity }\end{array}$ & Other \\
\hline Short course & $\square$ & $\square$ & $\square$ & $\square$ & $\square$ & \\
\hline Teaching placement & $\square$ & $\square$ & $\square$ & $\square$ & $\square$ & \\
\hline Research placement & $\square$ & $\square$ & $\square$ & $\square$ & $\square$ & \\
\hline Small Research Grant & $\square$ & $\square$ & $\square$ & $\square$ & $\square$ & \\
\hline Post-activity tutoring & $\square$ & $\square$ & $\square$ & $\square$ & $\square$ & \\
\hline
\end{tabular}




\begin{tabular}{|l|c|c|c|c|c|c|}
\hline $\begin{array}{l}\text { Professional } \\
\text { Development award }\end{array}$ & $\square$ & $\square$ & $\square$ & $\square$ & $\square$ & \\
\hline $\begin{array}{l}\text { Course on Writing and } \\
\text { presentation skills }\end{array}$ & $\square$ & $\square$ & $\square$ & $\square$ & $\square$ & \\
\hline $\begin{array}{l}\text { Annual Scientific } \\
\text { Meeting }\end{array}$ & $\square$ & $\square$ & $\square$ & $\square$ & $\square$ & \\
\hline HRDI listlink & $\square$ & $\square$ & $\square$ & $\square$ & $\square$ & \\
\hline HRDI website & $\square$ & $\square$ & $\square$ & $\square$ & $\square$ & \\
\hline HRDI Newsletter & $\square$ & $\square$ & $\square$ & $\square$ & $\square$ & \\
\hline $\begin{array}{l}\text { Technical assistance in } \\
\text { writing for publication }\end{array}$ & $\square$ & $\square$ & $\square$ & $\square$ & $\square$ & \\
\hline
\end{tabular}

D6. In general, what are your thoughts on the HRDI?

\begin{tabular}{|l|c|c|c|c|c|}
\hline & $\begin{array}{c}\text { Very } \\
\text { good }\end{array}$ & Good & $\begin{array}{c}\text { Neither } \\
\text { good } \\
\text { nor } \\
\text { poor }\end{array}$ & Poor & $\begin{array}{c}\text { Very } \\
\text { poor }\end{array}$ \\
\hline Content and type of activities met RF needs & $\square$ & $\square$ & $\square$ & $\square$ & $\square$ \\
\hline Quality of activities & $\square$ & $\square$ & $\square$ & $\square$ & $\square$ \\
\hline Administration of HRDI program & $\square$ & $\square$ & $\square$ & $\square$ & $\square$ \\
\hline Communication between HRDI team and RFs & $\square$ & $\square$ & $\square$ & $\square$ & $\square$ \\
\hline
\end{tabular}

Any additional comments?

D7. What do you find the most valuable contribution of the HRDI program?

1. Teaching opportunity

2. Learning opportunity

3. Research opportunity

4. Networking 
5. Dissemination of research findings

6. Publication opportunities

7. Writing skill

8. English

9. Other:

D8. Do you apply what you've learned from HRDI activities to your work?
1. Yes
2. No

If yes, please provide an example:

D9. HRDI aims to encourage RFs to play leading roles in this capacity building program. Would you consider taking on a more proactive role?
1. Yes
2. No

D10. If yes, what do you think you can contribute to HRDI activities?

D11. If no, why not?

Thank you so much for your cooperation.

Your feedback is greatly appreciated. 



\section{(2) Population Council}

41 Le Hong Phong Str - Ba Dinh Dist - Hanoi - Viet Nam

Tel: + 84 - 4 - 37345821

Fax: $+84-4-37345827$

Website: www.popcouncil.org 